\title{
Functional genomics of lactic acid bacteria: from food to health
}

\author{
François P Douillard', Willem M de Vos ${ }^{1,2,3^{*}}$ \\ From 11th International Symposium on Lactic Acid Bacteria \\ Egmond aan Zee, the Netherlands. 31 August - 4 September 2014
}

\begin{abstract}
Genome analysis using next generation sequencing technologies has revolutionized the characterization of lactic acid bacteria and complete genomes of all major groups are now available. Comparative genomics has provided new insights into the natural and laboratory evolution of lactic acid bacteria and their environmental interactions. Moreover, functional genomics approaches have been used to understand the response of lactic acid bacteria to their environment. The results have been instrumental in understanding the adaptation of lactic acid bacteria in artisanal and industrial food fermentations as well as their interactions with the human host. Collectively, this has led to a detailed analysis of genes involved in colonization, persistence, interaction and signaling towards to the human host and its health. Finally, massive parallel genome re-sequencing has provided new opportunities in applied genomics, specifically in the characterization of novel non-GMO strains that have potential to be used in the food industry. Here, we provide an overview of the state of the art of these functional genomics approaches and their impact in understanding, applying and designing lactic acid bacteria for food and health.
\end{abstract}

\section{Introduction \& outline}

Lactic acid bacteria (LAB) and humans share a long and intricate history. Well known are the first food fermentations reported in ancient times that contributed to the preservation and quality improvement of raw plant, meat and milk substrates. Most likely the transition from hunter-gatherers to an agricultural lifestyle, some 10,000 years ago, contributed to the further development of these food fermentations that are now practiced worldwide on an industrial scale. However, our interactions with $\mathrm{LAB}$ are more intimate and have a much longer history than the food fermentations that were initiated by the LAB present at that time (Figure 1). In addition to many plants and animals, the human body is also colonized by LAB and early culturing studies already documented the presence of LAB at different locations, $e$. $g$. the gastro-intestinal tract or the oral cavity [1]. However, many microbes cannot yet be cultured and this also holds for LAB [2]. Until recently, technological

\footnotetext{
* Correspondence: willem.devos@wur.nl

'Department of Veterinary Biosciences, University of Helsinki, Agnes

Sjöberginkatu 2, 00790 Helsinki, Finland

Full list of author information is available at the end of the article
}

limitations precluded the global characterization of human microbiota in terms of composition, diversity and dynamics. Massive parallel sequencing and other high throughput approaches have offered novel ways to explore and examine the microbiota from different human body cavities [3-5]. Much attention has been given to the human gastro-intestinal (GI) tract but the number of endogenous (autochtonous) LAB in the human system is rather low (Douillard and De Vos, in press; see also below). This contrasts with many animals where the GI-tract is a well-established habitat for high numbers of endogenous LAB, such as the fore-stomach of mice and other rodents, as well as the crop of chicken and other birds $[6,7]$. Hence, these animal systems, similar to many plants that are colonized with LAB in the phyllosphere, may constitute reservoirs for LAB found in food fermentations or even the human body (Figure 1).

In retrospect, it may be argued that the low level of endogenous $L A B$ in human explains the impact of passenger (allochtonous) LAB on the human host, as exemplified with LAB that are marketed as probiotics and after consumption have shown to provide health benefits $[8,9]$. The continuing consumer interest in these and 


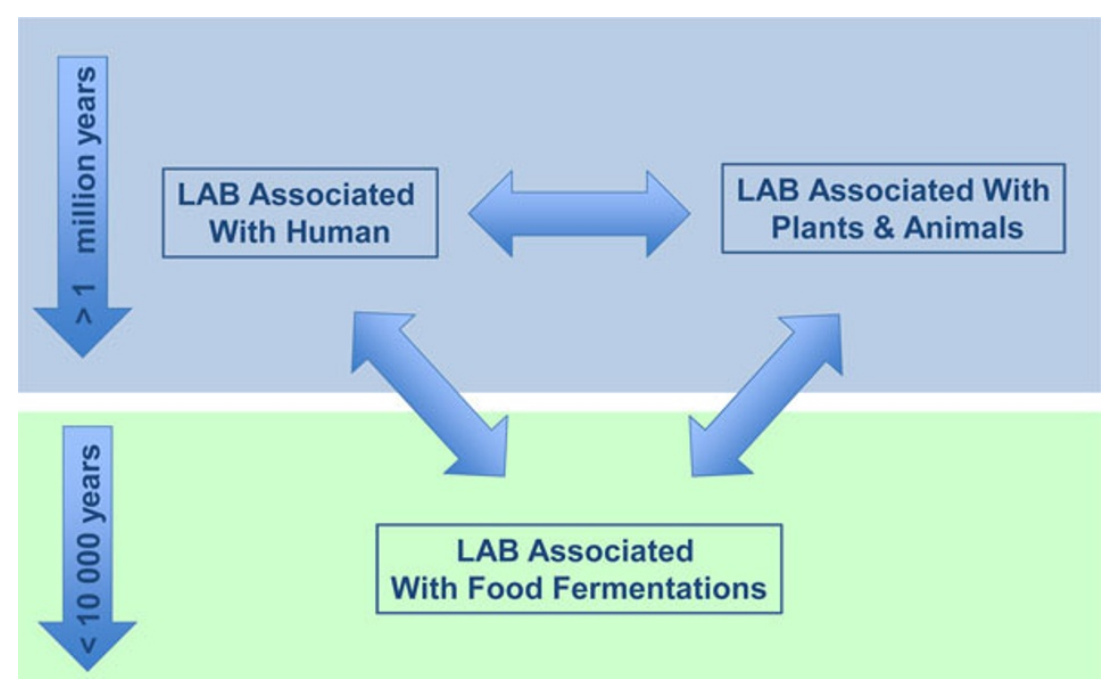

Figure 1 Overview of LAB associations with plants and animals, human and foods. The estimated time frames of the evolutionary events relating to the emergence of human (top) and domestication (bottom) are indicated - please note their different dimensions. For a further explanation, see text.

other LAB-containing functional foods may be a reason for the special fondness for these bacteria that go beyond any personal affection [10]. This interest has a long history as the first association of LAB with traditional fermentations, naturalness and long life, has been described over 100 years ago for what is now known as Lactobacillus delbrueckii subsp. bulgaricus [11]. Moreover, it is widely known that LAB are highly versatile and include phylogenetically related bacterial taxa that are essentially non-pathogenic.

The early days of the genome sequencing era witnessed a strong focus on pathogens, starting with Haemophilus influenza in 1995 [12]. In hindsight, this medical focus explains why the first LAB genomes were only deciphered some years later, in the early 2000s with Lactococcus lactis subsp. lactis [13] and Lactobacillus plantarum [14]. Ever since, the number of sequenced LAB genomes has grown exponentially and currently genomic data from over 100 LAB species and strains are available in various public databases. These offer a wealth of information, to further understand LAB with respect to their gene content, their properties, and their ecological role in human health as well as in food fermentations [15]. The present review aims at discussing and describing the latest functional genomic advances in LAB species that are associated with food and health (Figure 1). As prototype functional genomics studies rely on a complete genome sequence, we focus here on the LAB that comply with this criterion and these include rod-shaped LAB (Lactobacillus) and a dozen coccoid LAB, including Lactoccoccus, Streptococcus, Enterococcus, Pediococcus spp. and Oenococcus spp. (Table 1). Remarkably, this morphological distinction is reflected in a dichotomy in the genome-based phylogenetic tree (Figure 2). We will specifically focus on food-related fermentations where much basic progress has been on the global expression control using transcriptome and proteome approaches that are facilitated by the fact that these systems are easily accessible or can be mimicked in the laboratory. In contrast, the human associated LAB are more difficult to access and most studies that will be discussed relate to LAB with clear health benefits to the human host. Finally, we will address the evolutionary impact of the genomic adaptations (Figure 1) and describe some of the latest genomics approaches applied to LAB for improved food fermentations or health benefits.

\section{Functional genomics of LAB in food fermentations}

The use of LAB in industrial fermentations represents a multi-billion dollar industry with the dairy products cheese and yoghurt as the most produced commodities [16]. Hence, considerable attention is given to the function of LAB during the fermentation of milk into the final product. The most important LAB used as starters in these dairy fermentations are Lactococcus lactis, Streptococcus thermophilus, Lactobacillus delbruekii subsp. bulgaricus, while in some cases also some Leuconostoc or other Lactobacillus spp. are used. Representative strains of these starter bacteria have been genomically characterized (Table 1) [16]. However, in many cases the genome sequences of industrial starter strains have not been determined yet or not been made available in public databases. This is exemplified by the case of the cheese starters that in most cases belong to Lactococcus lactis subsp. cremoris. In addition to the genomes of strain MG163 and its derivative NZ9000, 
Table 1 Genomic features of a selected number of lactic acid bacteria related to human lifestyle and health.

\begin{tabular}{|c|c|c|c|c|c|c|c|}
\hline Bacterial species & $\begin{array}{c}\text { Example of } \\
\text { Sequenced Strain }\end{array}$ & Isolation Source & Genome Size (Mbp) & $\begin{array}{l}\text { Number of } \\
\text { Plasmids }\end{array}$ & $\% G C$ & Number of Proteins & References \\
\hline \multicolumn{8}{|l|}{ Lactobacilli } \\
\hline $\begin{array}{l}\text { Lactobacillus acidophilus } \\
\text { Lactobacillus amylovorus } \\
\text { Lactobacillus brevis } \\
\text { Lactobacillus buchneri } \\
\text { Lactobacillus casei } \\
\text { Lactobacillus crispatus } \\
\text { Lactobacillus delbrueckii subsp. bulgaricus } \\
\text { Lactobacillus fermentum } \\
\text { Lactobacillus gasseri } \\
\text { Lactobacillus helveticus } \\
\text { Lactobacillus iners } \\
\text { Lactobacillus jensenii } \\
\text { Lactobacillus johnsonii } \\
\text { Lactobacillus kefiranofaciens subsp. kefiranofaciens } \\
\text { Lactobacillus paracasei subsp. casei } \\
\text { Lactobacillus plantarum } \\
\text { Lactobacillus reuteri } \\
\text { Lactobacillus rhamnosus } \\
\text { Lactobacillus ruminis } \\
\text { Lactobacillus salivarius subsp. salivarius } \\
\text { Lactobacillus sakei subsp. sakei }\end{array}$ & $\begin{array}{l}\text { NCFM } \\
\text { GRL1112 } \\
\text { ATCC } 367 \\
\text { ATCC } 11577 \\
\text { BL23 } \\
\text { EM-LC1 } \\
\text { ATCC } 11842 \\
\text { IFO } 3956 \\
\text { ATCC } 33323 \\
\text { DPC 4571 } \\
\text { AB-1 } \\
\text { 269-3 } \\
\text { NCC } 533 \\
\text { ZW3 } \\
\text { N1115 } \\
\text { WCFS1 } \\
\text { DSM 20016 } \\
\text { GG } \\
\text { ATCC 25644 } \\
\text { UCC118 } \\
\text { 23K }\end{array}$ & $\begin{array}{l}\text { Gl tract (Feces) } \\
\text { Pig Gl Tract (Feces)* } \\
\text { Unknown } \\
\text { Oral Cavity } \\
\text { Food (Cheese) } \\
\text { Gl Tract (Feces) } \\
\text { Food (Dairy product) } \\
\text { Food (Plant) } \\
\text { Human origin } \\
\text { Food (Cheese) } \\
\text { Vaginal Cavity } \\
\text { Vaginal Cavity } \\
\text { Gl Tract (Intestine) } \\
\text { Food (Kefir) } \\
\text { Food (Dairy products) } \\
\text { Oral Cavity (Saliva) } \\
\text { Gl Tract (Intestine) } \\
\text { GI Tract (Intestine) } \\
\text { Gl Tract (Intestine) } \\
\text { GI Tract (Intestine) } \\
\text { Food (Meat) }\end{array}$ & $\begin{array}{c}1.99 \\
2.13 \\
2.34 \\
2.86 \\
3.08 \\
1.83 \\
1.87 \\
2.1 \\
1.89 \\
2.08 \\
1.29 \\
1.69 \\
1.99 \\
2.35 \\
3.06 \\
3.35 \\
2.0 \\
3.01 \\
2.07 \\
2.13 \\
1.88\end{array}$ & $\begin{array}{c}0 \\
2 \\
2 \\
\text { n.d. } \\
0 \\
\text { n.d. } \\
0 \\
0 \\
0 \\
0 \\
0 \\
\text { n.d. } \\
0 \\
2 \\
4 \\
3 \\
0 \\
0 \\
0 \\
3 \\
0\end{array}$ & $\begin{array}{l}34.7 \\
38.1 \\
46.0 \\
39.5 \\
46.3 \\
37.0 \\
49.7 \\
51.5 \\
35.3 \\
37.1 \\
32.7 \\
34.4 \\
34.6 \\
37.4 \\
46.5 \\
44.4 \\
38.9 \\
46.7 \\
43.7 \\
33.0 \\
41.3\end{array}$ & $\begin{array}{l}1,832 \\
2,121 \\
2,218 \\
3,002 \\
2,997 \\
1,751 \\
1,529 \\
1,843 \\
1,755 \\
1,610 \\
1,209 \\
1,575 \\
1,821 \\
2,162 \\
2,985 \\
3,063 \\
1,900 \\
2,913 \\
2,153 \\
2,013 \\
1,871\end{array}$ & $\begin{array}{c}{[112]} \\
{[195]} \\
{[19]} \\
D S \\
{[196]} \\
\text { DS } \\
{[19]} \\
{[197]} \\
{[19]} \\
{[113]} \\
{[154]} \\
\text { DS } \\
{[198]} \\
{[199]} \\
{[200]} \\
{[201]} \\
D S \\
{[69]} \\
{[111]} \\
{[106]} \\
{[202]}\end{array}$ \\
\hline \multicolumn{8}{|l|}{ Lactococci } \\
\hline $\begin{array}{l}\text { Lactococcus lactis subsp. lactis } \\
\text { Lactococcus lactis subsp. cremoris }\end{array}$ & $\begin{array}{l}\text { IL1403 } \\
\text { MG1363 }\end{array}$ & $\begin{array}{c}\text { Food (Cheese) } \\
\text { Food (Dairy Products) }\end{array}$ & $\begin{array}{l}2.37 \\
2.53\end{array}$ & $\begin{array}{l}0 \\
0\end{array}$ & $\begin{array}{l}35.3 \\
35.7\end{array}$ & $\begin{array}{l}2,277 \\
2.434\end{array}$ & $\begin{array}{l}{[13]} \\
{[203]}\end{array}$ \\
\hline \multicolumn{8}{|l|}{ Streptococci } \\
\hline $\begin{array}{l}\text { Streptococcus salivarius } \\
\text { Streptococcus thermophilus }\end{array}$ & $\begin{array}{l}\text { CCHSS3 } \\
\text { CNRZ1066 }\end{array}$ & $\begin{array}{l}\text { Oral Cavity } \\
\text { Food (Yoghurt) }\end{array}$ & $\begin{array}{c}2.22 \\
1.8\end{array}$ & $\begin{array}{l}0 \\
0\end{array}$ & $\begin{array}{l}39.9 \\
39.1\end{array}$ & $\begin{array}{l}2,027 \\
1,914\end{array}$ & $\begin{array}{l}\text { DS } \\
{[181]}\end{array}$ \\
\hline \multicolumn{8}{|l|}{ Enterococci } \\
\hline $\begin{array}{l}\text { Enterococcus faecalis } \\
\text { Enterococcus faecium }\end{array}$ & $\begin{array}{l}\text { V583 } \\
\text { DO }\end{array}$ & $\begin{array}{l}\text { Clinical Sample (Blood) } \\
\text { Clinical Sample }\end{array}$ & $\begin{array}{l}3.36 \\
3.05\end{array}$ & $\begin{array}{l}3 \\
3\end{array}$ & $\begin{array}{l}37.4 \\
37.9\end{array}$ & $\begin{array}{l}3,264 \\
3,114\end{array}$ & $\begin{array}{l}{[204]} \\
{[205]}\end{array}$ \\
\hline \multicolumn{8}{|l|}{ Oenococci } \\
\hline Oenococcus oeni & PSU-1 & Food (Plant) & 1.78 & 0 & 37.9 & 1,691 & [19] \\
\hline \multicolumn{8}{|l|}{ Pediococcus } \\
\hline $\begin{array}{l}\text { Pediococcus pentosaceus } \\
\text { Pediococcus claussenii }\end{array}$ & $\begin{array}{c}\text { ATCC } 25745 \\
\text { ATCC BAA-344 }\end{array}$ & $\begin{array}{l}\text { Food (Plant) } \\
\text { Food (Beer) }\end{array}$ & $\begin{array}{l}1.83 \\
1.98\end{array}$ & $\begin{array}{l}0 \\
8\end{array}$ & $\begin{array}{l}37.4 \\
37.0\end{array}$ & $\begin{array}{l}1,752 \\
1,881\end{array}$ & $\begin{array}{c}{[19]} \\
{[182]}\end{array}$ \\
\hline \multicolumn{8}{|l|}{ Leuconostoc } \\
\hline $\begin{array}{l}\text { Leuconostoc mesenteroides } \\
\text { Leuconostoc citreum } \\
\text { Leuconostoc gelidum } \\
\text { Leuconostoc carnosum } \\
\text { Leuconostoc kimchi } \\
\text { Leuconostoc gasicomitatum }\end{array}$ & $\begin{array}{l}\text { ATCC } 8293 \\
\text { KM20 } \\
\text { JB7 } \\
\text { JB16 } \\
\text { IMSNU } 11154 \\
\text { LMG 18811T }\end{array}$ & $\begin{array}{l}\text { Food (Olives) } \\
\text { Food (Kimchi) } \\
\text { Food (Kimchi) } \\
\text { Food (Kimchi) } \\
\text { Food (Kimchi) } \\
\text { Food (Spoilage) }\end{array}$ & $\begin{array}{c}2.08 \\
1.9 \\
1.89 \\
1.77 \\
2.1 \\
1.95\end{array}$ & $\begin{array}{l}1 \\
4 \\
0 \\
4 \\
5 \\
0\end{array}$ & $\begin{array}{l}37.7 \\
38.9 \\
36.7 \\
37.1 \\
37.9 \\
36.7\end{array}$ & $\begin{array}{l}2,003 \\
1,820 \\
1,796 \\
1,691 \\
2,129 \\
1,912\end{array}$ & $\begin{array}{l}{[19]} \\
{[136]} \\
{[206]} \\
{[207]} \\
{[208]} \\
{[209]}\end{array}$ \\
\hline
\end{tabular}

Legend: DS, Direct Submission to sequence databases; n.d, not defined; *, No human isolates have been sequenced yet. Due to some discrepancies between the original references and the sequence databases, the data shown in the table were exclusively retrieved from NCBI databases as on 4th of April 2014. 


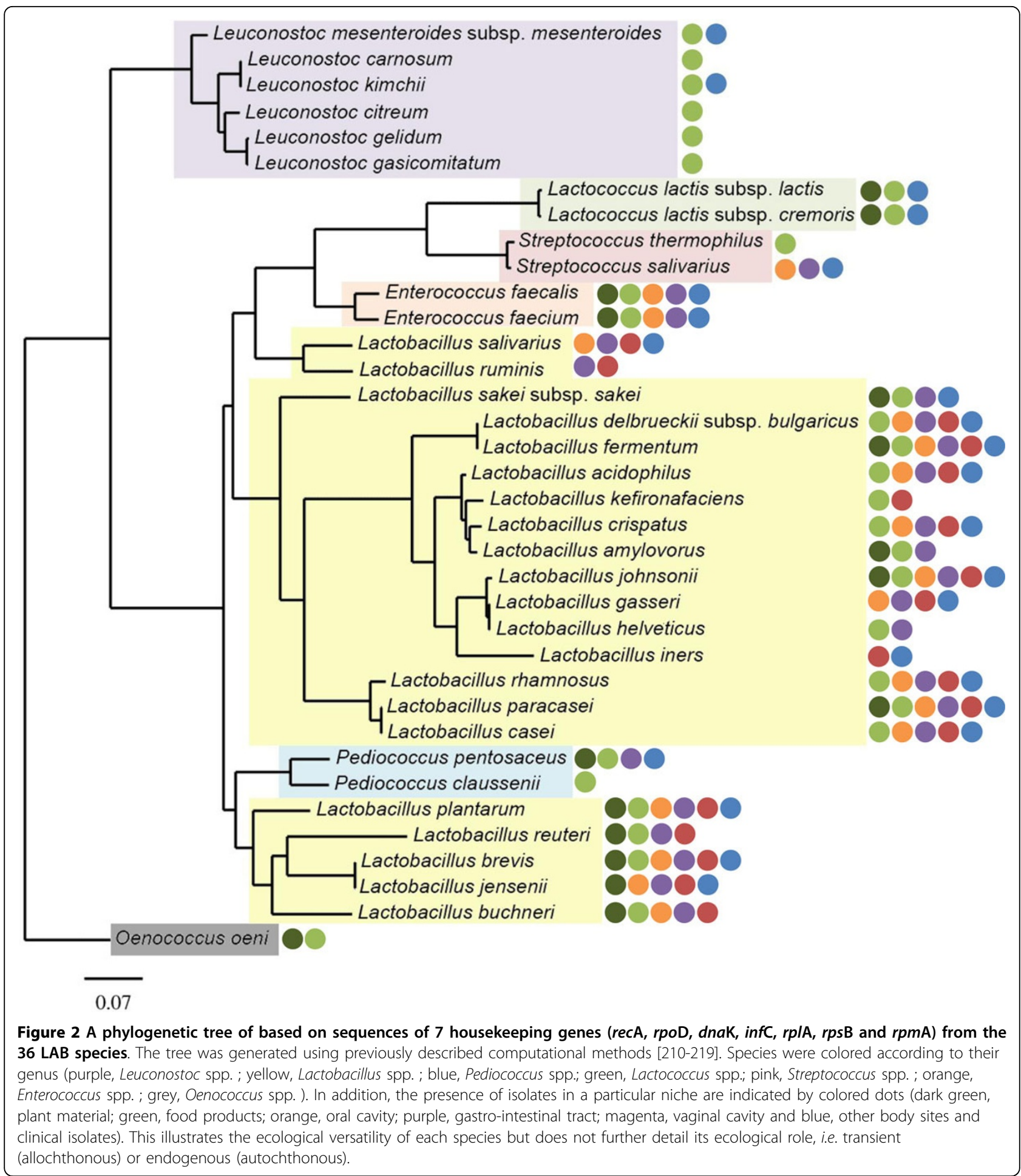

widely used as a host with the NICE system $[17,18]$, only 4 other complete genomes of this taxon have been reported. These genomes include their plasmid complement, which is of crucial importance as it harbors many important dairy functions [16]. The first strain was SK11, a well-studied good flavor-producing strain used as model in earlier genetic studies $[19,20]$. More recent examples include strain A76, isolated from a cheese production system and strain UC 509.9, an Irish starter with the smallest genome [21]. Moreover, the complete genome of Lactococcus lactis subsp. cremoris KW2, derived from a corn-fermentation, has been elucidated [22]. This and another plant isolate, 
Lactococcus lactis subsp. lactis KF147, isolated from mung bean sprouts, with one of the largest lactococcal genomes [23], serve as models for domestication studies (Figure 1) and will be discussed below.

In recent years genomic interest has developed into the so called Non-Starter LAB (NSLAB) that are naturally present in dairy fermentations and in some cases have been developed into adjunct starters that contribute to flavor development or quality improvement of fermented foods $[24,25]$. An example is the recent genomic characterization of Lactobacillus helveticus strain CNRZ 32, used as an adjunct starter to reduce bitterness and found to encode 4 different cell-envelope proteinases, in contrast to other Lactobacilli that have one or none [26].

A variety of functional genomics approaches have been reported in the last decade that relate to $\mathrm{LAB}$ found in food fermentations. Most have focused on the dairy LAB and here we will discuss the salient features of the common elements that relate to the control of gene expression and serve as models for other LABs. Moreover, functional studies have targeted a variety of foods where attention has been focused on starter LAB, NSLAB and spoilage LAB. Finally, in these studies a series of discoveries have been described that affect the lifestyle of LAB and these are briefly summarized.

\section{Growth \& global regulation}

$\mathrm{LAB}$ are known to be rather fastidious bacteria that compete based on rapid growth and lactic acid production in a selected number of habitats (see Figure 2) Genomic-based metabolic reconstructions and modeling have confirmed the dependence on external sources of sugar and protein that are found in complex media such as milk, meat and some plant materials. So much attention has been focusing on the control of carbon and nitrogen metabolism.

By far the most important factor controlling sugar degradation in $L A B$ is the catabolite control protein CcpA. The first ccpA gene of LAB was discovered in Lactococcus lactis MG1363 and found to act as a transcriptional activator of the lactic acid synthesis (las) operon with the order $p f k-p y k$-ldh [27]. Using sensitive microarray analysis in wild-type MG1363 and an isogenic $c c p A$ deletion strain, the time-dependent global regulon was uncovered and allowed the identification of 82 CcpA binding sites, known as catabolite responsive elements (cre), predicting the role of CcpA in sugar transport and other metabolic processes [28]. Recently, a high-resolution crystal structure of the $76 \mathrm{kDa}$ homodimer has been solved and a first analysis of the interaction between the cre sites and CcpA has been made for the cellobiose operon $[29,30]$. New aspects on the role of CcpA in global control are continuously being uncovered by using transcriptional and proteomic studies in many LAB [31-35]. Moreover in other cocci besides Lactoccocus spp., CcpA is an important control system, as demonstrated in Streptococcus thermophilus and Enterococcus faecalis [36,37]. In an elegant metabolic and transcriptional study it was recently found that resting cells of MG1363 at pH 5.1 showed enormous pools of lactic acid, reaching levels of $700 \mathrm{mM}$ inside the cells [38]. Apart from various stress-response genes and the membrane bound ATPase genes, also various glycolytic genes belonging to the las operon were overexpressed. Another recent study addressed the transcriptional network of Lactococcus lactis MG1363 in milk and identified CcpA as one of the major regulators in addition to others that are discussed below. Moreover, 2 new potential CcpA target sites were identified and are suggested to be involved in fine tuning of the CcpA mediated control [39]. The organization of the ccpA gene in many LAB is such that it is juxtaposed but divergently transcribed from the prolidase-encoding pep $Q$ gene, indicating a link between carbon and nitrogen metabolism, as first observed in Lactococcus lactis MG1363 [28]. While carbon control is highly relevant for LAB, the tight control of nitrogen metabolism may be even more important as amino acid synthesis is a costly cellular process.

Several nitrogen control systems are present in LAB and the most studied include GlnR and CodY. While GlnR is present in all LAB genomes, CodY is only present in Lactocccus, Streptococcus and Enterococcus spp. [40]. A comparative genomic study of GlnR regulon, revealed its target site to be present in all LAB genomes and, supported by published transcriptome analyses, predicted GlnR to be involved in controlling the import of nitrogen-containing compounds and the synthesis of intracellular ammonia under conditions of high nitrogen availability [40]. In Lactococcus lactis MG1363 GlnR was found to be rather specific but CodY appeared to be a much more global control system [41]. This appeared to be the cases for all other coccoid LAB where it is present. Similar to the identification of the CcpA regulon, a comparative transcriptome approach using an isogenic $\operatorname{cod} Y$ mutant was followed to identify the CodY regulon in Lactococcus lactis MG1363 [42]. Over 30 genes mainly involved in amino acid metabolism were identified to be under control of CodY in strain MG1363 and in later study in strain IL1403 some more were predicted based on the CodY target (CodY box) in the genome of this strain [43]. The CodY box is present in the promoter of the $\operatorname{cod} Y$ gene, explaining that $\operatorname{cod} Y$ regulates its own synthesis and does so in response to branched chain amino acids [42]. Importantly, CodY controls the proteolytic system of Lactococcus lactis and notably the cell-wall proteinase (PrtP), the key enzyme in milk degradation that prior to the genomic era was shown to be controlled at the transcriptional level by milk-derived 
peptides [44]. During growth of strain MG1363 in milk, CodY also acts as a regulator of a major network and detailed transcriptional studied identified a second CodY box in the intergenic regions of 3 operons but the function of this element remains enigmatic in absence of further experimental work [39]. An integrated transcriptomic and proteomic analysis of the adaptation of strain IL1403 to isoleucine starvation showed that CodY was specifically dedicated to the control of the supply of this branched chain amino acid [45]. In Streptococcus thermophilus CodY was found to be also involved in the control of the proteolytic system but the study failed to identify a conserved CodY box, indicative of a species-specific cisacting control elements [46]. Remarkably, CodY in pathogenic Streptococci was shown to provide a link between amino acid and carbon metabolism as well as virulence factors such as nasopharynx colonization and the synthesis of exoproteins $[47,48]$. It would be of interest to determine whether CodY of Streptococcus salivarius has a similar role in the colonization of this and related species in the oral or other human related cavities (see below). The absence of a $\operatorname{cod} Y$ gene in the genomes of Oenococcus and Pediococcus suggests that these bacteria have a life style where they do not need such an intricate protein control [40]. Alternatively, these bacterial species may employ different regulatory mechanisms, possibly involving unrecognized regulators.

Apart from the above-mentioned CcpA, GlnR and CodY, many other specific and global regulators have been described and functionally studied. In many cases new links may be observed as the control systems all seem to be interlinked. With the development of high throughput transcriptome and RNAseq approaches, new avenues to identify and map these are emerging. The recent analysis of the global regulatory networks, identified during growth of Lactococcus lactis subsp. cremoris MG1363 in milk, is such an example [39]. This is expected to be followed by other studies that will provide insights into the global control, the cis-acting elements, and their nodes. The challenge is to relate these transcriptional networks to the metabolic networks that are now well-developed to increase the predictability of LAB in the model systems, in food products and in association with human [49].

\section{Expression in foods}

To improve the understanding of growth and function of LAB in fermented foods, numerous global transcriptional, proteomic and recently also metabolomic studies have been performed. Model and starter strains of Lactococcus lactis have been the first to be studied. A lactoseproficient derivative of the model strain MG1363 was used in an artificial cheese system using an expression technology approach [50]. While a series of genes involved in amino acid transport and metabolism were identified, the approach suffered from the fact that the strain used was plasmid-free and did not contain the PrtP-encoded system and hence was not proteolytic. This caveat also applies to the elegant study of strain MG1363 in milk elucidating the global networks [39]. However, several other studies have addressed the expression in cheese of starter lactococci that are capable of rapid growth in milk. Using cheeses made from milk concentrated by ultrafiltration (UF-Cheese) and the starter Lactococcus lactis subsp. lactis biovar diacetylactis LD6, a detailed study was made of the in situ global gene expression [51]. Genes of the proteolytic system were increased due to down-regulation of CodY repression, while acid and oxidative stress-related genes were increased. Moreover, carbon limitation was apparent and involved release of CcpA-mediated control. In similar UF-Cheeses made with strain LD6, recently the metabolites were determined using an unsupervised mass-spectometry approach, illustrating the power of other nontargeted functional approaches [52]. In an unrelated study, four Lactococcus lactis subsp. cremoris starter strains (SK11, and proteolytic variants of HP, Wg2 and E8) were used in parallel cheese vats and analyzed for their transcriptomic response [53]. This resulted in the definition of a core transcriptome with almost 200 genes, mainly encoding for house-keeping functions but also those involved in cysteine metabolism. Several of these were found to be under control of the CodY regulator, reiterating the common theme discussed above. As indicated below, correlations between CcpA, CodY and the stringent response exist and it is expected that these regulatory circuits are all operating during these complex fermentations in cheese making. As often mixtures of LAB strains are used as cheese starter cultures, various approaches have been developed to differentiate between the components of the starter. Various metagenomics and quantitative PCR approaches have been tested and shown to have potential for strain differentiation or expression [54,55]. Sequence analysis of $16 \mathrm{~S}$ rRNA transcripts has recently been used to identify the microbial composition and activity of Cheddar cheese batches, identifying both LAB and NSLAB. These and similar investigations can be coupled to RNAseq studies to analyze the expression in real time of the different components.

Only few other global gene expression studies have been performed in food products other than those derived from fermented milk. The global transcriptome of Lactococcus garviae, a fish and opportunistic human pathogen was analyzed and revealed a heme-dependent and cold-induced respiration system [56]. This had already been described some years ago in another strain of Lactococcus garviae [57]. Such a respiration system was also identified in a transcriptomic approach of 
Leuconostoc gasicomitatum, an emerging food spoilage organism, when grown in meat [58]. The endogeneous heme present in meat allowed respiration and this increased growth rate and yield. Interestingly, this had no impact on the transcriptional response of Leuconostoc gasicomitatum, similar to what has been observed in Lactococcus lactis [59]. However, it has been described that the meat-grown Leuconostoc gasicomitatum respiration activity was increased 1000 -fold and was paralleled by the production of different metabolites, suggesting that its control is at the metabolic rather than the transcriptional level [58].

\section{Novel insight and functions}

While providing a molecular understanding of the adaptation of LAB to the food environment, the genomics studies discussed here also present insight in novel functions. An example is the identification of a novel stress regulon under the control of the protein Ldb0677 in Lactobacillus delbrueckii subsp. bulgaricus by using a proteomic approach and its characterization by molecular techniques [60]. Moreover, studies in other model systems may shed new light on the findings in LAB. One such new insight derives from findings in Bacillus subtilis, which reportedly shares a common ancestor with the LAB [19]. It has recently been shown that CcpA forms complexes with CodY in Bacillus subtilis and there is no reason to assume this would not be possible in LAB [61]. This strongly suggests that the carbon and nitrogen control in LAB are intimately connected. Similarly, structural analysis of the Bacillus subtilis CodY indicated that GTP is a ligand for this conserved regulator and hence CodY reacts to (p)ppGpp levels formed in the stringent response [62-64]. The stringent response of the (p)ppGpp alarmone may well be one of the general triggers that operate in LAB during cheese fermentation.

The discovery of aerobic respiration in LAB and its genetic elucidation has been well documented together with its biotechnological application [59]. This hemedependent property has now been found to be operating in many LAB, including several Lactobacillus, Leuconostoc and Enterococcus spp. [57,65,66]. Strictly speaking respiration is the coupling of a membrane potential to the reduction of oxygen and this only has been shown to operate in Lactococcus lactis subsp. cremoris MG1363 when grown on heme [67]. It is of interest to note that this respiration is so widely spread and appears to occur in food fermentations when there is a supply of hemecontaining media. Remarkably, also the genome of Oenococcus oeni contains the genes for aerobic respiration but its functionality has not yet been tested [67].

By an elegant combination of genomics and expression studies, it has been shown that the Lactococcus lactis model strains IL1403 contains the genes for pili production that can be expressed and are involved in biofilm production [68]. Prior to this discovery such proteinaceous pili had only been described in the GI tract isolate Lactobacillus rhamnosus GG where they bind human mucus as well as have a set of other functions, e.g. immunogenicity $[69,70]$. The presence of these functional pili genes in strain IL1403 prompted comparative genomics studies that revealed their presence in various Lactococcus lactis strains, including the other model strain MG1363, the plant isolate KF147 (see above), and various other plant and human isolates [68]. The presence of pili production genes in dairy and plant strains suggests that this property is multifunctional and provides competitive advantage in various environments. Interestingly, by using a combination of proteomics and genomics, a functional pili cluster that enables mucus binding was also detected in another plant isolate, strain TIL448 [71]. Here, the genes for the pili production are located on a plasmid, suggesting horizontal gene transfer and proving a possible mechanism for the apparently wide spread of this novel function in dairy and plant lactococci.

\section{Functional genomics of LAB in human health}

The colonization of LAB in and on the human body has been well established and 16S rRNA-based phylogenetic studies have identified LAB at different body sites, such as the skin, oral cavity, GI tract, and vaginal cavity [72-77]. Further comprehensive phylogenetic and metagenomic characterizations of the human-associated microbiota using massive parallel sequencing, have extended this notion and identified the presence, level and genetic content of the various LAB in the microbial communities in the human body [4,5]. Based on these data it can be concluded that the number of total microbes varies considerably in the various body sites, as does the fraction of LAB (Figure 3).

The recent genome-based molecular inventories have shown that the fraction of LAB in the GI-tract is low and barely reaches over $1 \%$ in only few persons (Figure 3 ). It is assumed that many of these LAB are passengers rather than endogenous inhabitants. Still, a detailed phenotypic and genomic characterization of strains from each LAB species is needed to clarify their role within the GI tract, since some LAB have a high intraspecies diversity and include both endogeneous and passenger strains. This has been confirmed in human feeding studies with marked Lactococcus lactis, showing unexpected survival of viable cells [78]. Moreover, a recent high fat feeding trial where fecal DNA was analysed using massive parallel sequencing, revealed the transit of Lactococcus lactis, Streptococcus thermophilus and Pediococcus acidilacti, which are components of dairy and meat starters [79]. However, based on genomic or 


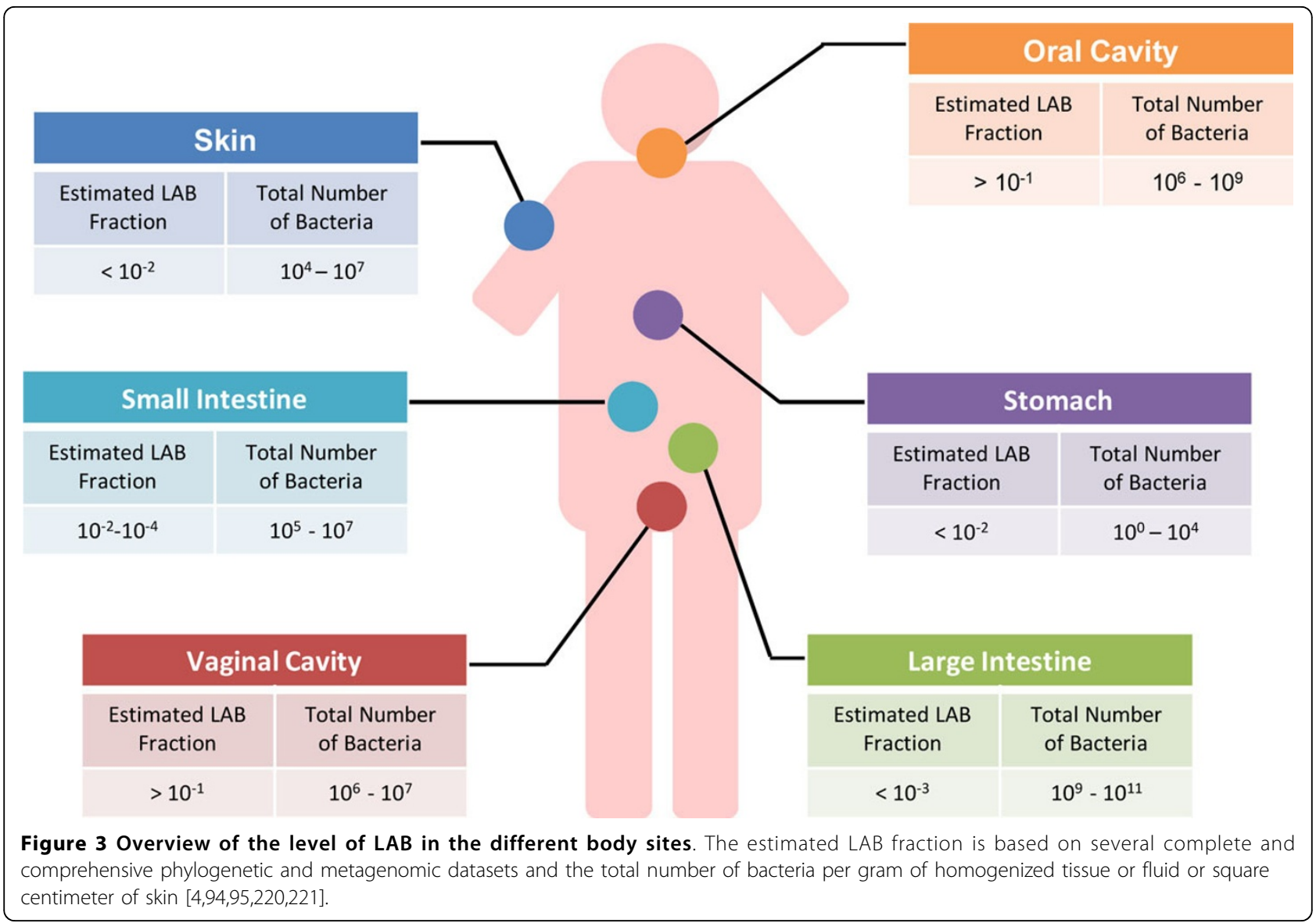

sequence characteristics various LAB strains have found to be endogenous in human $[56,73,75,80]$. By far the highest fractions of LAB are found in the oral and vaginal cavities since the environment of these relatively open systems is more accessible than that of the human GI tract (Figure 3).

While our mouth as the port d'entrée of the GI tract is receiving a rather variable microbial load of mainly passengers, the vaginal cavity has a rather stable microbiota. This explains why the endogeneous vaginal LAB were found to be specifically associated with health [81]. This contrasts with the GI tract where most specific associations with health have been described for other members of the complex human-associated communities than LAB [82]. An exception is a recent metagenome study, where Lactobacillus gasseri was associated with the incidence of type 2 diabetes in a Swedish cohort [83]. However, this was not reproduced in another large type 2 diabetes cohort and the observed genes may have derived from passenger LAB [84].

As many of the genomes of human-derived LAB have been determined (Figure 2), we summarize the recent functional genomics studies of these strains below.

\section{The oral cavity}

The mouth constitutes the first cavity from which food is introduced into the digestive tract. As an ecological habitat, it hosts hundreds of different bacterial species, including LAB, that are colonizing the teeth, the gum, the saliva and various locations on the tongue [4]. Teeth, as hard tissues, form an excellent surface for biofilm formation [85]. A dozen Lactobacilli are found to be the most prevalent LAB detected in the oral cavity (Figure 2) [86,87]. Metaproteomic analysis also confirmed the presence of Lactobacilli in the human saliva [88]. Some LAB have been used to restore healthy oral microbiota and the well-known probiotic Lactobacillus rhamnosus GG was shown to reduce the population of Streptococcus mutans, the common cause of caries [89]. Genomic and phenotypic characterization of oral isolates of Lactobacillus rhamnosus indicated that these were closely related to cheese isolates, suggesting that they may originate from food products [80]. However, genomic characterization of Lactobacillus rhamnosus strains isolated from dental pulp showed that these were unique and contained an additional set of approximately 250 unique genes [90]. These genes included those 
coding for the biosynthesis of exopolysaccharides that could be involved in biofilm formation, while others encoded transcriptional regulators and ferric iron $A B C$ transporters. In the oral isolates of both studies, the spaCBA-srtC1 pilus gene cluster was lacking, suggesting that such trait is not essential for persisting in the oral cavity $[80,90]$.

\section{The gastro-intestinal tract}

Isolated or detected throughout the whole digestive tract, LAB only represent a minor proportion of gastro-intestinal microbial communities [73,91]. Typically, representatives of the Lactobacillus/Enterococcus group constitute $0.01-1.8 \%$ of the overall fecal microbiota, as shown by qPCR techniques [92]. Their abundance in the GI tract significantly ranges from less than $10^{4} \mathrm{CFU} / \mathrm{ml}$ (small intestine) to $10^{6} \mathrm{CFU} / \mathrm{g}$ (faeces) (Figure 3) [73,74,93-95]. The human small intestine was shown to harbour a diverse population of Streptococci [96]. However, sequence analysis of the rRNA gene does not allow determining whether these detected LAB strains are endogenous or transient. Up to date, more than 20 LAB species have been detected in the digestive tract (Figure 2). Some of these are consumed as probiotics, such as Lactobacillus plantarum, Lactobacillus casei or Lactobacillus rhamnosus $[8,10,97]$. Others are present in the mouth where they may be derived from food or be endogenous (see above). This suggests that some of the LAB isolated from the GI tract may in fact originate from food or the oral cavity $[96,98,99]$.

Detailed comparative and functional genomic characterization of human LAB isolates may provide answers whether they are endogenous or transient, as well as generate a better understanding of their ecological fitness, their adaptation, and their role in their dedicated niche. The first of these studies related to Lactobacillus johnsonii and Lactobacillus gasseri, which were genomically characterized ten years ago (Table 1). Genomic data complemented with experimental work provide evidence for the ecological adaptation and fitness of Lactobacillus gasseri to the GI tract, as recently reviewed [100]. Transcriptomic analysis of Lactobacillus johnsonii NCC533 identified a number of genes that could relate to its persistence within the intestinal tract [101]. The isolation and sequencing of intestinal LAB along with $\mathrm{LAB}$ from other sources has allowed us to compare strains and to determine the diversity of each species from an ecological but also evolutionary perspective. In a recent comparative genomic study, the examination of 100 Lactobacillus rhamnosus isolates showed possible correlations between ecological fitness, phenotypic traits and genomic modifications [80]. The intraspecies diversity in Lactobacillus rhamnosus was mostly concentrated in 17 lifestyle islands. Compared to Lactobacillus rhamnosus food isolates, a subset of GI tract isolates harbored more prevalently genes associated with specific carbohydrate pathways (fucose metabolic genes), host adhesion (mucus-binding SpaCBA pilus gene cluster), defence and immunity system (CRISPR system) and biofilm formation (exopolysaccharide cluster). These are likely to provide an improved capacity to colonize and persist in the GI tract [80]. Intestinal Lactobacillus rhamnosus isolates were shown to be resistant to bile, whereas isolates from dairy niches for example were generally less bileresistant [80]. Two other closely related species Lactobacillus casei and Lactobacillus paracasei shared some lifestyle islands with Lactobacillus rhamnosus that were syntenous [102,103]. Using hybridization arrays and multilocus sequence typing, the genomic diversity of Lactobacillus salivarius was studied [104]. In line with findings in other $\mathrm{LAB}$, the intraspecies diversity was found to be concentrated on 18 chromosomal regions that included gene clusters encoding for the production of exopolysaccharides [104]. An important fitness factor with applied potential is the capacity to produce a broad host-range bacteriocin that allowed Lactobacillus salivarius to outcompete Listeria monocytogenes [105]. In addition to chromosomal variations, the presence of plasmids and other mobile elements are playing an important role. One remarkable example contributing to intraspecies diversity is the presence of megaplasmids in some Lactobacillus salivarius strains. Lactobacillus salivarius subsp. salivarius UCC118 harbors the megaplasmid pMP118 (242 kb in size) [106]. Further analysis of two other subspecies identified other megaplasmids with a different size, suggesting a possible role in ecological adaptation [106].

Some species such as Lactobacillus reuteri are specialized to one particular host. Lactobacillus reuteri is also commonly in different human body sites, i.e. breast milk, GI tract, vagina but it is also found in other vertebrates $[107,108]$. Work on the Lactobacillus reuteri species revealed that strains have distinctly evolved between different hosts. Gut isolates from different mammals, i.e. rodents and humans have distinct genetic signatures. This may be explained by the fact that the anatomical differences between human and rodent gut resulted in different colonization strategies [109]. The host specialization observed among Lactobacillus reuteri strains results from similar genetic mechanisms as in other symbiotic bacteria [109]. The role played by transposases in the genome dynamics between rodent and human isolates differs. The genomes of Lactobacillus reuteri human gut isolates tends to be smaller with higher number of pseudogenes [109], as previously reported in other hostdependent bacteria [110]. In contrast with the Lactobacillus reuteri strains, where it was shown that strain differ according to the host, comparative genomic analysis showed that the human gut strain Lactobacillus ruminis 
ATCC 25644 is highly similar to the bovine isolate Lactobacillus ruminis ATCC 27782 [111]. They, however, significantly differ from the closely related Lactobacillus salivarius (Figure 3). Lactobacillus acidophilus and Lactobacillus helveticus are closely related (Figure 2). However, Lactobacillus helveticus is typically more specialized to the dairy environment compared to the gutadapted Lactobacillus acidophilus, which has conserved more biological functions. In the Lactobacillus helveticus genome, adhesion factors, such as mucus-binding proteins, are absent along with a narrower gene repertoire encoding for PTS transporters [112,113].

Genome sequences of $\mathrm{LAB}$ provided a basis to identify the secretome and interactome of LAB found in the human GI tract. Within the Lactobacillus casei group, the respective LPXTG protein-encoding gene repertoires of Lactobacillus rhamnosus, Lactobacillus casei and Lactobacillus paracasei shared several similarities [102]. Among others, pilus gene clusters were identified. However, only in Lactobacillus rhamnosus, the functionality and expression of one of the gene cluster encoding mucus-binding pili (spaCBA-srtC1) has been so far demonstrated $[69,114]$. This single and outstanding trait contributes to the highly efficient adhesion of Lactobacillus rhamnosus GG to the intestinal mucosa [69]. Within the Lactobacillus rhamnosus species, pilus-associated genes were significantly more present in intestinal isolates (56 \%) compared to dairy isolates (13\%) [80]. Genome-wide analysis of Lactobacillus salivarius UCC118 identified 108 predicted secreted proteins, including 10 sortase-anchored proteins. Gene deletion of sortase and one sortase-anchored protein significantly reduced the epithelium-binding ability of the strain UCC118 [115]. A recent review discussed the central role of sortases and LPXTG proteins for LAB, especially for the ones found in the GI tract [116]. Interestingly, some Lactobacillus ruminis strains, i.e. ATCC 27782, also possess a set of genes encoding for a complete and functional flagellar apparatus, i.e. 45 flagellar genes, providing motility [117]. The discovery of motile commensal LAB suggests unique and uncovered impact on the gut ecology in terms of host signaling and colonization. In the intestinal Lactobacillus gasseri ATCC 33323, among the 271 predicted cell surface proteins, at least 14 mucus-binding proteins were identified [118], suggesting a potential role in adherence with the intestinal mucosa. In Lactobacillus acidophilus L-92, the attachment to epithelial cell lines altered the expression of 78 genes, i.e. membrane proteins, transporters and regulators [119]., Comparative proteomic analysis led to the identification of 18 proteins with potential adhesive properties, including surface-layer protein A. Further work showed that the latter protein has a central role in the adherence of Lactobacillus acidophilus L-92 to epithelium [120]. Moreover, one of the well-characterized surface-layer proteins, SlpA of Lactobacillus acidophilus NCFM, was found to bind to the DC-SIGN receptor of dendritic cells, indicative of a role in intestinal signaling $[121,122]$.

A number of similarities in terms of response to the GI environment have been observed among gut-isolated $\mathrm{LAB}$ species and relate among others to metabolic rerouting, cell wall modifications or activation of resistance/stress mechanisms. The mechanisms by which these genes are induced when LAB are in the human gut are not fully comprehended. Specific attention has been given to the exposure to bile salts and acids as during the transit (and eventual colonization) in the GI tract, LAB are exposed to these environmental stimuli. Recent proteomic and transcriptomic analysis of the intestinal Lactobacillus rhamnosus strain GG under bile stress revealed the activation of numerous genes related to cell wall functions and possibly operate as a stimulus for adherence in the intestinal tract [123]. Lactobacillus rhamnosus strain GG also generated a specific response towards acid environments, as examined by proteomic analysis [124]. Similarly, in Lactobacillus casei BL23, 52 proteins showed an altered expression under bile stress, and these were predicted to be involved in general stress response, cell wall functions and also carbohydrate metabolism [125]. Remarkably, in Lactobacillus acidophilus, glycogen metabolism was found to be associated with bile resistance [126]. Apart from these laboratory studies also a series of model animal and human studies have been reported. An in vivo expression technology (IVET) study in Lactobacillus plantarum WCFS1 identified a set of 72 genes that were induced when transiting the GI tract of mice [127]. These mainly include genes associated with carbohydrate metabolism, biosynthetic pathways and transport and also four genes potentially relating to host interactions, i.e. cell wall anchor proteins [127]. Reciprocally, Lactobacillus plantarum WCFS1 cells triggered the expression of over 400 genes in the mucosa of the human small intestine $[128,129]$. A mouse study further addressed the transcriptional responses of Lactobacillus plantarum to different dietary regimes [130]. Finally, the transcriptional responses to Lactobacillus plantarum WCFS1 in mice and human were described in a detailed comparative study that revealed high level similarities between those systems [131]. The transcriptomic profile of Lactobacillus plantarum WCFS1 was also found to be modified upon exposure to p-coumaric acid, a component present in vegetables or fruits, possibly signaling Lactobacillus plantarum to its entry to the digestive tract [132]. Similarly, the transcriptional response of Lactobacillus plantarum to bile was also investigated, revealing a set of genes whose expression is bile-inducible [133]. Within the 
Lactobacillus plantarum species, strains have different bile sensitivity, i.e. showing either resistance (strain 299V) or sensitivity (strain LC56) [134]. Comparative proteomic analysis of three different strains led to the identification of 13 proteins related to bile resistance mechanisms [134]. In addition, alteration of genes associated with cell surface proteins and metabolism suggests that Lactobacillus plantarum underwent adaptation when exposed to the murine tract [135]. In intestinal isolates of Lactobacillus reuteri, a total of 28 genes were shown to be induced under bile salt exposure and proteomic analysis indicated that the encoded proteins were associated with metabolic pathways, stress-induced response and also $\mathrm{pH}$ homeostasis, which possibly relate to resistance mechanisms of Lactobacillus reuteri to bile salt stress [136]. A similar mechanistic response was observed when exposed to acids [137]. Mice studies showed that the transcriptome of Lactobacillus johnsonii NCC533 is changing throughout the GI tract, suggesting specific responses to each of the GI sites [138]. Using a mouse model, it was found that 174 Lactobacillus johnsonii NCC533 genes were expressed in vivo, including EPS-associated glycosyltransferase genes and PTS transporters [101].

In conclusion, $\mathrm{LAB}$ when present in the GI-tract express a number of common characteristics that relates their adaptation. These could be summarized as follows: $i$. a large repertoire of genes encoding transporters (ABC, PTS or permeases) to optimally utilize nutrients available in the gut niche, $i i$. the presence of genes associated with acid and bile resistance, iii. a wide range of genes promoting interactions and signaling with the host, such as pili that contain mucus-binding proteins.

\section{The vaginal cavity}

LAB members constitute a dominant proportion $(\sim 80 \%)$ of bacteria inhabiting the vaginal cavity of healthy women [139] and are consistently detected in healthy vaginal microbiota from patients of different ethnic groups and/or living in different geographical locations [139-143]. Four main bacterial species were typically identified: Lactobacillus crispatus, Lactobacillus iners, Lactobacillus jensenii and Lactobacillus gasseri along with, at lesser extent, some other lactobacilli, such as Lactobacillus acidophilus, Lactobacillus ruminis, Lactobacillus rhamnosus or Lactobacillus vaginalis $[139,144-146]$. The high abundance of LAB is strongly associated with healthy vagina, whereas a low abundance of $\mathrm{LAB}$, i.e. alteration of the vaginal microbiota, was more prevalent in women with a medical condition, i.e. bacterial vaginosis (BV) $[140,145,147]$. The beneficial roles of LAB in preserving a healthy vagina include the maintenance of acidic vaginal $\mathrm{pH}$ [148], the prevention of infections by producing bacteriocins, hydrogen peroxide and acids, but also by signaling to the host [148-150]. The understanding of the vaginal microbiota composition not only contributes to the comprehension of the ecology of this habitat in health and disease but also offers avenues towards the development of better diagnostic and therapeutic solutions [147,151,152].

Four LAB species are predominantly detected in human vagina (Lactobacillus crispatus, Lactobacillus gasseri, Lactobacillus iners and Lactobacillus jensenii) but co-dominance between LAB species is seldom [142]. This indicates that each vaginal species may harbor genes that relate to (unique) adaptation signatures and allow the non-symbiontic persistence and colonization regardless of the presence of other LAB members [153]. Interestingly, these $\mathrm{LAB}$ genomes also showed to be significantly smaller and contained a lower GC content than other LAB genomes, suggesting a loss of nonessential genes towards a vaginal adaptation [153].

One of the most studied vaginal LAB is the Lactobacillus iners. Remarkably, strains from the Lactobacillus iners species have a relatively small genome compared to the $\mathrm{LAB}$, i.e. $\sim 1.3 \mathrm{Mb}$ for Lactobacillus iners $\mathrm{AB}-1$ genome [154] and its intraspecies diversity is peculiarly low [143]. In line with its genome size, Lactobacillus iners is not able to biosynthesize many vitamins, cofactors and amino acids, while compensating these metabolic limitations by the presence of numerous genes encoding transporters [154]. When compared to Lactobacillus crispatus, Lactobacillus gasseri and Lactobacillus jensenii, Lactobacillus iners carries a variety of unique genes encoding $\mathrm{ABC}$ transporters [153]. The poor metabolic and biosynthetic capabilities illustrate its strong dependency to the host niche, from where Lactobacillus iners acquires most of its nutrients. This may also explain why this species is rarely detected in other ecological niches that are more demanding in terms of metabolic capabilities [155,156]. Lactobacillus iners is lacking numerous transcriptional regulators or integral membrane proteins [153]. The detailed mechanisms involved the persistence of Lactobacillus iners in the vagina remain unclear. However, a number of genes encoding potential adhesins (a total of 11 LPXTG proteins) were identified in Lactobacillus iners AB-1 [154], along with genes encoding fibronectin-binding type adhesins [157], indicating that interactions occur between the bacterial cells and the vaginal tissues. Such association (lactobacilli-epithelium) promotes exclusion of pathogens [158], as shown with the displacement of biofilms formed by Gardnerella vaginalis [159]. In addition, Lactobacillus iners AB-1 is able to use mucin as a carbon source, which is clearly beneficial for persisting in a mucosal niche (vagina) [154]. Interestingly, the genome of Lactobacillus iners AB-1 contains a gene (LINAB_0216) that encodes a cytolysin [154]. This gene is also found in other Lactobacillus iners isolates and its 
product is similar to cholesterol-dependent cytolysins produced in species such as Streptococcus or Gardnerella, [160]. However, its function in L. iners is unclear, i.e. attachment to host tissues, antimicrobial activity or pathogenesis $[143,160]$. A recent meta-RNA-seq based study showed that during a BV episode Lactobacillus iners AB-1 modified the expression of genes encoding the CRISPR-cas system, the cholesterol-dependent cytolysin and the mucin and glycerol transporters [81]. This underlines adaptive mechanisms towards the persistence of Lactobacillus iners in changing vaginal microbiota, i.e. change of nutrient use (mucin and glycogen) and protection against bacteriophages [81]. The overexpression of the cholesterol-dependent cytolysin by Lactobacillus iners during BV appeared to have a detrimental role towards the host [152]. Based on genomic and transcriptomic data, Lactobacillus iners was found to be specifically adapted the vaginal niche under different conditions, i.e. healthy or non-healthy vaginal microbiota. This remarkable adaptation suggests a strong association of Lactobacillus iners with the host, possibly contributing to maintaining a healthy microbiota, though its role in BV needs to be further examined.

In contrast with the Lactobacillus iners species, strains of all three other vaginal LAB, Lactobacillus crispatus, Lactobacillus gasseri and Lactobacillus jensenii are also found in other ecological niches than the vagina (Figure 2). Intestinal Lactobacillus gasseri isolates have genotypic traits beneficial for persistence and colonization in the gut (see above) [118]. Comparative genomic analysis identified a series of species- and/or niche-specific gene sets mostly consisting of different $\mathrm{ABC}$ transporters and regulators and in some cases toxin-antitoxin systems or cell envelope proteins [153]. However, no clear vaginal gene sets were defined in Lactobacillus crispatus, Lactobacillus gasseri and Lactobacillus jensenii. Vaginal strains of Lactobacillus crispatus have a larger genome than other strains of this species, possibly resulting from an abundance of ISencoded transposases [153].

Apart from the four dominant LAB species that are recurrently detected in healthy vaginal microbiota, also other Lactobacillus spp., can be found and show, in some cases, unique patterns in both phenotypes and genomes (Figure 2). In a recent study, vaginal Lactobacillus rhamnosus isolates were compared with the Lactobacillus rhamnosus strain GG at both genomic and phenotypic level [80]. Four main genotypic/phenotypic traits were highlighted: the lack of mucus-binding pili, their bile resistance (100\% of all isolates), an altered or deficient CRISPR-cas system compared to strain GG and some metabolic capabilities similar to food isolates. It was hypothesized that vaginal LAB may have originated from food environments or the oral cavity and survived through the gastro-intestinal tract (bile resistant, antimicrobial activity), before colonizing the vaginal cavity [80]. The loss of the pilus gene cluster indicates that it is not beneficial for Lactobacillus rhamnosus in the vaginal cavity. This is consistent with genomic data on other vaginal $\mathrm{LAB}$, such as Lactobacillus iners, Lactobacillus gasseri or Lactobacillus crispatus, with genomes that does not contain such cluster. Recent work on other $\mathrm{LAB}$, i.e. Lactobacillus plantarum, showed that the vaginal adhesion of the bacterial cells is sortase-dependent and therefore relies on LPXTG anchor proteins that likely do not form pili [161]. Similar mechanisms may occur as well in other LAB, such as Lactobacillus rhamnosus. No other studies on vaginal Lactobacillus rhamnosus genomics have been reported but it seems that only a subset of the Lactobacillus rhamnosus species may be able to colonize the vaginal cavity. Most clinical trials using Lactobacillus rhamnosus strains showed promising results $[162,163]$. However, each strain within the species appear to have a distinct ecological fitness and intestinal Lactobacillus rhamnosus strain GG with a pheno-genotype different from vaginal isolates, was poorly colonizing the vagina cavity, indicating that it lacks a number of genes promoting its ecological fitness to the vaginal cavity [164].

\section{Other body sites and clinical cases}

In general, LAB are considered to be safe and many species are on the list of Qualified Presumed Safety (QPS) of the European Food Safety Authority [165]. This does not apply to Enterococcus faecalis and Enterococcus faecium, two species of enterococci that have been and are used as starters in various food fermentations as well as marketed as probiotics (Figure 2) [166]. These enterococci emerged as the leading causes of antibiotic-resistant infection of bloodstream, urinary tract and surgical wounds [167]. However, most if not all human are carrying these Enterococcus spp. in their GI tract and it has been suggested that enterococci may have been ubiquitous colonizers of the gut since the early Devonian period, i.e. 400 million years ago [168]. Comparative genomic studies have now shed light on how such normal colonizing species may have developed into a major group of pathogens. It appeared that the genomes of hospital adapted enterococcal strains consist of over $25 \%$ of mobile elements, have lost CRISPR-cas systems that limit horizontal gene transfer, and have accumulated multiple antibiotic resistance and virulence traits [168]. It has been proposed that the introduction of antibiotics approximately 75 years ago and their widespread use in both human and veterinary medicine promoted the rapid evolution of the present epidemic hospital-adapted lineage not from human commensals but from a population that included animal strains [168]. There is some apparent disagreement about the moment of divergence between the 
commensal and hospital lineages of enterococci (300,000 versus 3000 years ago) $[168,169]$. However, it is tempting to assume that this occurred after the transition of the hunter-gatherer, possibly at a time of increasing urbanization of humans, development of hygienic practices, and domestication of animals as has proposed to contribute to the ecological separation of these lineages [168] (Figure 1). Interestingly, a comparative genomic study indicated that Enterococcus spp. and pathogenic Streptococci shared more gene families than did the genomes from non-pathogens, such as other LAB [170].

Inspection of the present QPS listing reveals that some LAB have incidental cases where they are implicated in non-nosocomial and other clinical infections. This has been described previously for Lactobacillus rhamnosus and has been recently reviewed [171]. However, the increased intake of Lactobacillus rhamnosus GG did not lead to an increase in bacteremia cases [172]. Hence, EFSA concluded that clinical infections especially of Lactobacillus rhamnosus, should be closely monitored [165]. This also relates to an increasing number of reports that imply LAB in other body sites than the canonical caveats (Figure 3). These include strains of Lactococcus lactis, Leuconostoc lactis, Lactobacillus casei, Lactobacillus paracasei and Pediococcus sp. [165]. The number of reports linking Lactococcus lactis, often the subsp. cremoris, to clinical cases is increasing. Recent studies include the isolation of Lactococcus lactis from human brain or neck abcesses or bovine mastitis [173-175]. It should be remembered that Lactococcus lactis (then appropriately termed Bacterium lactis) was the first bacterium grown as a pure culture by Joseph Lister in 1878. Ironically, Lister compared the fermentation process with an infection process in his attempts to illustrate the cause of infectious disease in humans [176]. It can be expected that further comparative and functional genomic studies of clinical, food and other LAB isolates will be instrumental in understanding the adaptations to the human body as well as assessing the safety of LAB used in the food or pharmacy industry.

\section{Evolutionary LAB genomics}

\section{Adaptation and horizontal gene transfer}

It is generally believed that plant material is the archetype source of the dairy LAB, though some inoculation from the dairy cow and its milk is also possible (Figure 1). Recent culture-independent analysis of the foliar microbiome, which is rapidly developing and the dairy cow's teat showed LAB to be present in both environments $[177,178]$. Hence, detailed genomic analysis is needed to distinguish between the sources of the dairy LAB. Comparing the genome of the plant isolate Lactococcus lactis subsp cremoris KW2 with the dairy strains showed remarkable similarities apart from the large 21-gene cluster coding for the biosynthesis of wall techoic acids that is partially absent or truncated in the model strain MG1363 or the dairy starters SK11, UC509.9 or A76. In contrast to the dairy starters, the plant strain KW2 does not contain any plasmids or IS sequences. This substantiates the earlier suggestions that these mobile elements are recent acquisitions by horizontal gene transfer. Moreover, the presence of the gene cluster for the wall techoic acid production seems to be a plant adaptation as it is also found in Lactococcus lactis subsp. lactis KF147 isolated from mung bean sprouts that has been studied extensively as a non-dairy model for lactococci [23]. This strain KF147 has one of the largest genomes, shows high identity and synteny to the genome of Lactococcus lactis subsp. lactis IL1403 but contains a variety of plant adaptations that have been lost in the dairy starter of this taxon $[23,179]$. Hence, for Lactococci there is ample evidence that plants are the sources of the dairy strains (Figure 2).

The genome Lactobacillus iners AB-1 is the smallest among the LAB (Table 1) suggesting that important gene loss occurred in that species towards the specialization to one unique ecological habitat, i.e. vaginal cavity. The genome size reduction possibly reflects the dependency of vaginal LAB to their host, as previously reported in other symbiotic bacteria, such as Candidatus Tremblaya princeps (genome size of $139 \mathrm{~kb}$ ) [180]. The limited coding capacities of Lactobacillus iners do not only reflect a remarkable ecological-driven specialization to the vaginal host but also a strong dependency to this habitat. The high number of genes associated with DNA repair, RNA modification and the alteration of a number of metabolic pathways clearly underline how most of these vaginal lactobacilli rely on the host for surviving and persisting. There is a potential mutualistic relationship between the host and the vaginal LAB. The host provides a stable environment, from where vaginal LAB can utilize nutrients (mucin, glycogen) or by-products from other inhabitants. In return, vaginal lactobacilli are warrant of the maintenance of a healthy vaginal microbiota. Although Lactobacillus iners has been reported in rare clinical cases [155], these may constitute evolutionary dead-ends that are usually not associated with any adaptation traits.

As detailed in the first large scale comparative genomic study, most LAB are phylogenetically closely related (Figure 2) but mainly differ by the gain of novel genes or the loss/decay of ancestral genes [19]. In addition, the number of pseudogenes is highly variable among LAB, i.e. S. thermophilus CNRZ1066 (182 pseudogenes) [181] or Pediococcus pentosaceus ATCC 25745 (19 pseudogenes) [19]. The presence of plasmids or megaplasmids in some strains are also of interest, since they may carry additional genes involved in metabolic pathways, production of bacteriocins and bile salt hydrolase. Two 
striking examples are: the co-existence of 8 plasmids in Pediococcus claussenii ATCC BAA-344 [182] and the presence of a 242-kb megaplasmid pMP118 in Lactobacillus salivarius UCC118 [106]. In addition, horizontal gene transfer further contribute to genus and species diversification, as previously reported in Lactobacillus acidophilus, Lactobacillus casei, Lactobacillus delbrueckii subsp. bulgaricus and Lactobacillus johnsonii [103,183-185]. Significant differences observed in LAB genomic features give primary evidence for possible ecological adaptation and specialization: genome size (coding capacities), pseudogenes or plasmids (Table 1). Only a further detailed examination of these genomes may highlight gained, duplicated, decayed or lost gene sets that are encoding biological functions relating to one particular ecological context. The role played by transposases in the genome dynamics between rodent and human isolates differs. The genomes of Lactobacillus reuteri human gut isolates tends to be smaller with higher number of pseudogenes [109], as previously reported in other host-dependent bacteria [110].

\section{Applied LAB genomics}

The use of functional and comparative genomics has greatly enhanced a variety of applications. First, there is the issue of strain identity and protection. Many manufacturers of LAB starters or producers that market $L A B$ as probiotics, have started to characterize their strains by complete genomic analysis. While supporting rapid strain characterization, this is also instrumental in strain mining and speedily selecting specific properties. Moreover, safety, administrative and legal processes can be supported by genome sequences and LAB strains of competitors can be benchmarked. With respect to safety, one should realize that knowledge of a genome sequence does not make a strain safe or not. However, lessons learned from the adaptation of notably Enterococcus strains discussed above could be helpful in further predicting safety of LAB.

The rapid implementation of next generation sequencing technologies for comparative genome analysis has allowed for several well-known commercial strains to be made public. It was recently shown that Lactobacillus casei strains marketed in Yakult and Actimel products were found to contain only a few dozen single nucleotide polymorphisms (SNPs) and a prophage [186]. This approach also showed that Lactobacillus rhamnosus GG isolated from several products was highly stable [114]. A new genomics approach that is only possible by the rapid advances in sequencing technology is capitalizing on genomic resequencing approaches. In a first published example Lactococcus lactis NZ9000, containing the nisRK two-component system genes that are used in conjunction with the nisin-controlled expression system, was mutated to increase expression of a variety of membrane proteins $[17,187]$. The genomes of the resulting 3 strains were compared and found to carry notably SNPs in the sensor NisK gene [17]. This coupling of adaptive evolution and high throughput sequencing has been used in many other studies with LAB, e.g. experimental evolution of Lactobacillus plantarum when exposed to the murine digestive tract [135]. A recent report describes an elegant study with the plant isolate Lactococcus lactis KF147 (see above) that propagated for 1000 generations in milk resulting in faster growth and biomass yields [188]. Three of the resulting strains were resequenced and found in two of the cases to have lost the conjugative transposon needed for growth in plants (see above). In the rest of the genome only few (6-28) mutations were detected in various genes, including those involved in amino acid production and transport. Remarkably, the strain with most mutations also contained a mutated mutL gene involved in mismatch repair and believed to increase the mutation frequency [188]. This example illustrates not only the power of experimental evolution and the used sequencing technology but also highlights the domestication process of a plant strain to the dairy environment.

A final but appealing approach where applied genomics has been used is the in the selection for Lactococcus lactis strains [189]. Cells of the strain MG1363 were mutagenized and serially propagated in water-inoil emulsions to allow for selection of strains with increased biomass yield. One of the resulting strains coupled an increased biomass to slightly different growth kinetics and the conversion from homolactic into a mixed acid fermentation. Genomic resquencing revealed a SNP mutation in the $p t n C$ gene, encoding a component of the glucose PTS transport system. The phenotype of this mutant is explained by decreased glucose uptake rates, resulting in less acidification and higher yields without $\mathrm{pH}$ control. A series of revertants were also isolated that upon genomic resequencing were found to contain an IS905 copy inserted in front of the $p \operatorname{tn} A B C D$ operon, resulting in upregulation of the glucose PTS transport [189]. While these experiments generated further insight in fundamental aspects of the adaptation processes they also represent the proof of concept on how to use high throughput screening and sequencing allowing rapid analysis of the results. The examples of applied genomics described here are only a few of the possibilities that can be envisaged. Notably, strain optimization in combination with genomic re-sequencing will be a highly useful tool for improving starter strains or LAB marketed as probiotics. As natural or induced mutations do not lead to genetically modified organisms, the generated and improved strains can be used immediately for food or pharmaceutical applications. 


\section{Concluding remarks}

Benefiting from the rapid development of next generation sequencing techniques, multiple genome sequencing projects on $\mathrm{LAB}$ were initiated since the beginning of the millennium. The data available up to now provide a comprehensive view on the complexity of the heterogeneous LAB group (Figure 2). Detailed comparative analysis of these genomic data emphasized the remarkable diversity within the LAB group at numerous taxonomic levels, i.e. order, family, group, genus and even species. This diversity results from the interactions between genome and environment as is schematically depicted (Figure 4). The abundance and variety of nutrients available in a habitat has a direct impact of the catabolic and biosynthetic properties of LAB. In many LAB species, the loss of metabolic genes is compensated by genome enrichment in genes encoding for transporters (ABC or PTS systems), allowing LAB to use nutrients and by-products from their niche. This specialization is evident from genome size reduction, presence of pseudogenes, and genome decay. Still, other LAB species or strains maintain a broad ecological flexibility, which may cause a high resilience to drastic environmental changes.
Because LAB are heterotrophs they have developed intimate interactions with plants and, most likely later, with animals and humans (Figure 1). Host-associated $\mathrm{LAB}$ contain a large and diverse repertoire of interaction proteins to adhere and signal to the host. It is tempting to speculate that the GI tract, as the site where plants enter the animal body, has played an important role in this evolutionary process. LAB adapted to the food environment may not require interaction with any host and therefore would generally possess a distinct repertoire of cell surface proteins. Thus, alternative surface proteins may be involved in the interactions between $L A B$ and food constituents as compared to the interplay with the host mucosa [190]. Horizontal gene transfer appears a major driver of the genomic diversity and plasticity, affecting genome size and the acquisition of new genes. Plasmids of different sizes (up to mega-plasmids) and conjugative transposons have found to be involved in gene gain and loss.

Surviving in a niche also means to compete with other microbes and to defend against other inhabitants, including bacteriophages. The controlled production of organic acids and antimicrobials is a highly effective strategy in this microbiological warfare. Moreover, LAB harbor

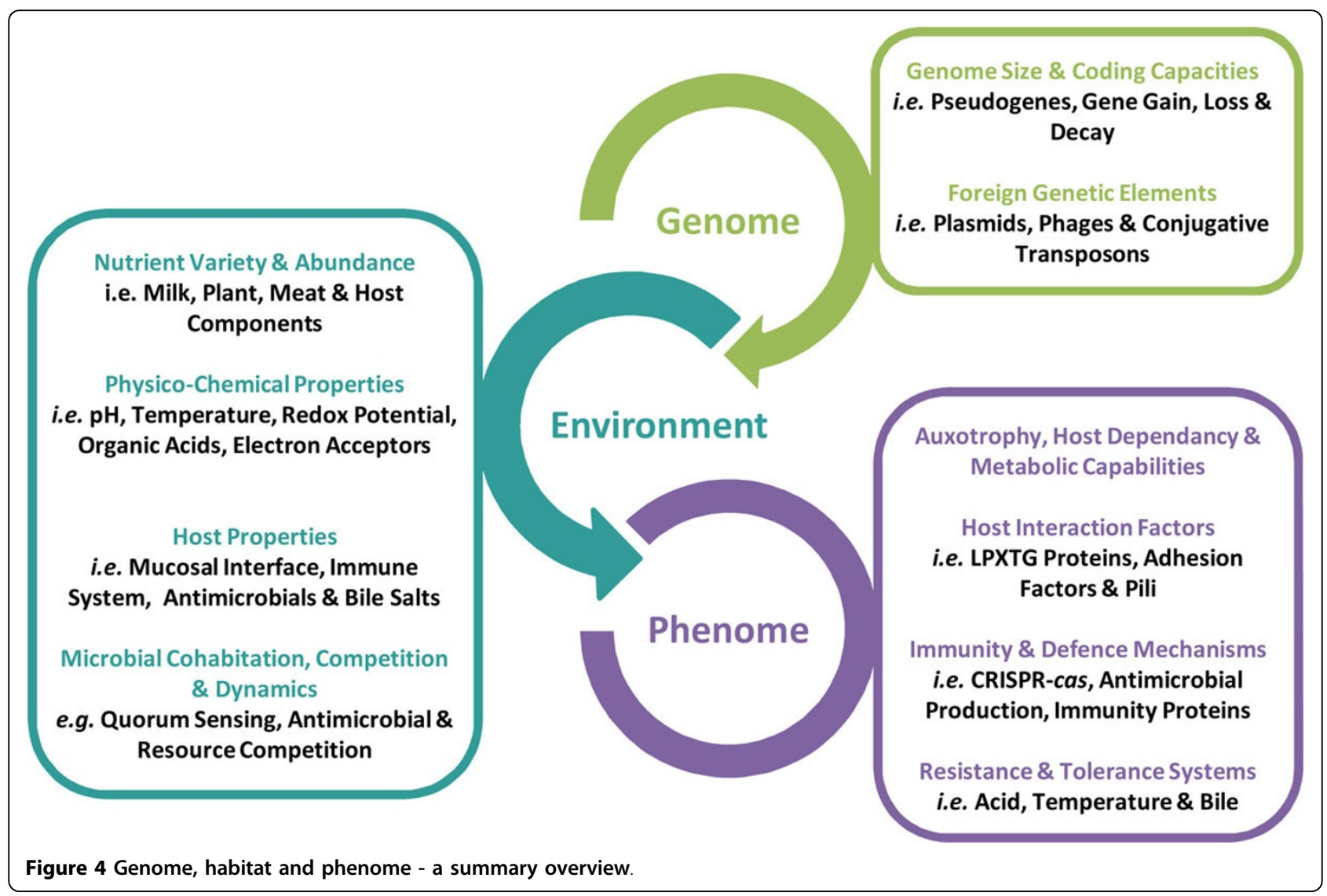


CRISPR-cas systems to protect from bacteriophages and other foreign DNA. It seems that the loss of these defense systems may promote the promiscuous transfer of various traits, including antibiotic resistance or virulence factors. Finally, tolerance and resistance systems to endure physico-chemical properties, such as temperature, acid, salt or bile salts, are essential for LAB living in foods, the GI tract or other harsh environments.

The area of host-microbe, microbe-microbe and microbe-molecule interaction is a highly relevant and timely theme, notably in view of the rapidly expanding interest in the human GI tract [191]. It may be expected that the insight worked out for LAB may serve as model for other microbes. Moreover, as many LAB have immediate application potential, these systems also may result in improved or novel strains or processes, as seen for the discovery of peptide-based quorum sensing in Lactococcus lactis [192]. Some of the models with impact at various levels include the CRISPR-cas system discovered in Streptococcus thermophilus [193], the communication of Lactobacillus plantarum with the human host [129], the production of host-interacting pili in Lactobacillus rhamnosus [69], the evolution of metabolic strategies in Lactococcus lactis [189] or the finding of a novel metal-depending lactate racemase in Lactobacillus plantarum that is widely distributed [194]. The discovery of these models has relied for a large part on functional genomics, stressing the importance of this approach in LAB. This provides a promising outlook for the future where soon all LAB species will be characterized at the genomic level, many strains will have been re-sequenced, and functional and applied genomics are implemented in academic and industrial environments, resulting in the further advancement of science and improvement of the quality of life.

\section{List of abbreviations used}

$B V$, bacterial vaginosis; DS, direct submission; Gl, gastro-intestinal; GMO, genetically-modified organisms; LAB, lactic acid bacteria; NSLAB, Non-Starter $L A B$.

\section{Competing interests}

The authors declare that they have no competing interests.

\section{Acknowledgements}

We are grateful to Prof. Todd R. Klaenhammer for his excellent contribution to the research on lactic acid bacteria for food and health during the last 40 years, his inspiration to many young and not-so young scientists, and his approval to us to contribute to this special issue. WMdV was sponsored by the European Research Council (ERC grant 250172 - Microbes Inside), the Academy of Finland (grant number 141130) and the Gravity and Spinoza Awards of the Netherlands Organization for Scientific Research. FPD was supported by the Academy of Finland (postdoctoral research fellowship, grant number 252123). We also thank Dr. Jarmo Ritari for generating the phylogenetic tree. We apologize that we could not cite all relevant research work on $L A B$ functional genomics due to space limitations and time constraints.

\section{Declarations}

This article has been published as part of Microbial Cell Factories Volume 13 Supplement 1, 2014: Proceedings of the 11th International Symposium on Lactic Acid Bacteria. The full contents of the supplement are available online at http://www.microbialcellfactories.com/supplements/13/S1. Publication charges for this supplement were funded by the Stichting Symposium on Lactic Acid Bacteria. The articles have undergone the journal's standard peer review process for supplements. EJ is employed by Chr Hansen A/S, is a shareholder in Chr Hansen A/S; and has applied for patents relating to the content of an article which he did not edit but which forms part of this supplement. MK is an employee of Nizo. The other Supplement Editors declare that they have no competing interests.

\section{Authors' details}

'Department of Veterinary Biosciences, University of Helsinki, Agnes Sjöberginkatu 2, 00790 Helsinki, Finland. 'Laboratory of Microbiology, Wageningen University, Dreijenplein 10, 6703 HB Wageningen, The Netherlands. ${ }^{3}$ Department of Bacteriology \& Immunology, University of Helsinki, Haartmaninkatu 3, 00014 Helsinki, Finland.

Published: 29 August 2014

\section{References}

1. Tannock GW: Normal microflora: an introduction to microbes inhabiting the human body. Springer; 1995

2. Vaughan EE, Heilig HGHJ, Ben-Amor K, de Vos WM: Diversity, vitality and activities of intestinal lactic acid bacteria and bifidobacteria assessed by molecular approaches. FEMS Microbiol Rev 2005, 29:477-490.

3. Zoetendal EG, Rajilić-Stojanović M, de Vos WM: High-throughput diversity and functionality analysis of the gastrointestinal tract microbiota. Gut 2008, 57:1605-1615.

4. Human Microbiome Project Consortium: Structure, function and diversity of the healthy human microbiome. Nature 2012, 486:207-214.

5. Qin J, Li R, Raes J, Arumugam M, Burgdorf KS, Manichanh C, Nielsen T, Pons N, Levenez F, Yamada T, et al: A human gut microbial gene catalogue established by metagenomic sequencing. Nature 2010, 464:59-65.

6. Sekelja M, Rud I, Knutsen SH, Denstadli V, Westereng B, Naes T, Rudi K Abrupt temporal fluctuations in the chicken fecal microbiota are explained by its gastrointestinal origin. Appl Environ Microbiol 2012, 78:2941-2948.

7. Frese SA, Mackenzie DA, Peterson DA, Schmaltz R, Fangman T, Zhou $Y$, Zhang C, Benson AK, Cody LA, Mulholland F, et al: Molecular characterization of host-specific biofilm formation in a vertebrate gut symbiont. PLoS Genet 2013, 9:e1004057.

8. Saxelin M, Tynkkynen S, Mattila-Sandholm T, de Vos WM: Probiotic and other functional microbes: from markets to mechanisms. Curr Opin Biotechnol 2005, 16:204-211

9. Petschow B, Dore J, Hibberd P, Dinan T, Reid G, Blaser M, Cani PD, Degnan FH, Foster J, Gibson G, et al: Probiotics, prebiotics, and the host microbiome: the science of translation. Ann N Y Acad Sci 2013, 1306:1-17.

10. Tannock GW: A special fondness for lactobacilli. Appl Environ Microbiol 2004, 70:3189-3194.

11. Douglas LM: The bacillus of long life. London: TC \& EC Jack; 1911.

12. Fleischmann RD, Adams MD, White O, Clayton RA, Kirkness EF, Kerlavage AR, Bult CJ, Tomb JF, Dougherty BA, Merrick JM, et al.: Wholegenome random sequencing and assembly of Haemophilus influenzae Rd. Science 1995, 269:496-512.

13. Bolotin A, Wincker P, Mauger S, Jaillon O, Malarme K, Weissenbach J, Ehrlich SD, Sorokin A: The complete genome sequence of the lactic acid bacterium Lactococcus lactis ssp. lactis IL1403. Genome Res 2001, 11:731-753.

14. Kleerebezem M, Boekhorst J, van Kranenburg R, Molenaar D, Kuipers OP Leer R, Tarchini R, Peters SA, Sandbrink HM, Fiers MWEJ, et al: Complete genome sequence of Lactobacillus plantarum WCFS1. Proc Natl Acad SC USA 2003, 100:1990-1995.

15. Johnson BR, Klaenhammer TR: Impact of genomics on the field of probiotic research: historical perspectives to modern paradigms. Antonie Van Leeuwenhoek 2014.

16. de Vos WM: Systems solutions by lactic acid bacteria: from paradigms to practice. Microb Cell Fact 2011, 10(Suppl 1):S2. 
17. Linares DM, Kok J, Poolman B: Genome sequences of Lactococcus lactis MG1363 (revised) and NZ9000 and comparative physiological studies. J Bacteriol 2010, 192:5806-5812.

18. de Ruyter PG, Kuipers OP, de Vos WM: Controlled gene expression systems for Lactococcus lactis with the food-grade inducer nisin. Appl Environ Microbiol 1996, 62:3662-3667.

19. Makarova K, Slesarev A, Wolf Y, Sorokin A, Mirkin B, Koonin E, Pavlov A, Pavlova N, Karamychev V, Polouchine N, et al: Comparative genomics of the lactic acid bacteria. Proc Natl Acad Sci USA 2006, 103:15611-15616.

20. de Vos WM, Vos P, de Haard H, Boerrigter I: Cloning and expression of the Lactococcus lactis subsp. cremoris SK11 gene encoding an extracellular serine proteinase. Gene 1989, 85:169-176.

21. Ainsworth S, Zomer A, de Jager V, Bottacini F, van Hijum SA, Mahony J, van Sinderen D: Complete genome of Lactococcus lactis subsp. cremoris UC509.9, host for a model lactococcal P335 bacteriophage. Genome Announc 2013, 1.

22. Kelly WJ, Altermann E, Lambie SC, Leahy SC: Interaction between the genomes of Lactococcus lactis and phages of the P335 species. Front Microbiol 2013, 4:257.

23. Siezen RJ, Bayjanov J, Renckens B, Wels M, van Hijum SAFT, Molenaar D, van Hylckama Vlieg JET: Complete genome sequence of Lactococcus lactis subsp. lactis KF147, a plant-associated lactic acid bacterium. J Bacteriol 2010, 192:2649-2650

24. Settanni L, Moschetti $\mathrm{G}$ : Non-starter lactic acid bacteria used to improve cheese quality and provide health benefits. Food Microbiol 2010, 27:691-697.

25. Papanikolaou Z, Hatzikamari M, Georgakopoulos P, Yiangou M, LitopoulouTzanetaki E, Tzanetakis N: Selection of dominant NSLAB from a mature traditional cheese according to their technological properties and in vitro intestinal challenges. J Food Sci 2012, 77:M298-306

26. Broadbent JR, Hughes JE, Welker DL, Tompkins TA, Steele JL: Complete genome sequence for Lactobacillus helveticus CNRZ 32, an industrial cheese starter and cheese flavor adjunct. Genome Announc 2013, 1.

27. Luesink EJ, van Herpen REMA, Grossiord BP, Kuipers OP, de Vos WM: Transcriptional activation of the glycolytic las operon and catabolite repression of the gal operon in Lactococcus lactis are mediated by the catabolite control protein CcpA. Mol Microbiol 1998, 30:789-798.

28. Zomer AL, Buist G, Larsen R, Kok J, Kuipers OP: Time-resolved determination of the CcpA regulon of Lactococcus lactis subsp. cremoris MG1363. J Bacteriol 2007, 189:1366-1381.

29. Loll B, Saenger W, Biesiadka J: Structure of full-length transcription regulator CcpA in the apo form. Biochim Biophys Acta 2007, 1774:732-736.

30. Aleksandrzak-Piekarczyk T, Polak J, Jezierska B, Renault P, Bardowski J: Genetic characterization of the CcpA-dependent, cellobiose-specific PTS system comprising CelB, PtcB and PtcA that transports lactose in Lactococcus lactis IL1403. Int J Food Microbiol 2011, 145:186-194.

31. Barrangou R, Azcarate-Peril MA, Duong T, Conners SB, Kelly RM, Klaenhammer TR: Global analysis of carbohydrate utilization by Lactobacillus acidophilus using CDNA microarrays. Proc Natl Acad Sci USA 2006, 103:3816-3821.

32. Andersen JM, Barrangou R, Hachem MA, Lahtinen SJ, Goh YJ, Svensson B, Klaenhammer TR: Transcriptional analysis of prebiotic uptake and catabolism by Lactobacillus acidophilus NCFM. PLoS One 2012, 7:e44409.

33. McLeod A, Snipen L, Naterstad K, Axelsson L: Global transcriptome response in Lactobacillus sakei during growth on ribose. BMC Microbiol 2011, 11:145.

34. Mazzeo MF, Cacace G, Peluso A, Zotta T, Muscariello L, Vastano V, Parente E, Siciliano RA: Effect of inactivation of ccpA and aerobic growth in Lactobacillus plantarum: A proteomic perspective. J Proteomics 2012. 75:4050-4061.

35. Muscariello L, Marino C, Capri U, Vastano V, Marasco R, Sacco M: CcpA and three newly identified proteins are involved in biofilm development in Lactobacillus plantarum. J Basic Microbiol 2013, 53:62-71.

36. van den Bogaard PTC, Kleerebezem M, Kuipers OP, de Vos WM: Control of lactose transport, beta-galactosidase activity, and glycolysis by CcpA in Streptococcus thermophilus: evidence for carbon catabolite repression by a non-phosphoenolpyruvate-dependent phosphotransferase system sugar. J Bacteriol 2000, 182:5982-5989.

37. Gao P, Pinkston KL, Bourgogne A, Cruz MR, Garsin DA, Murray BE, Harvey BR: Library screen identifies Enterococcus faecalis (cpA, the catabolite control protein $\mathrm{A}$, as an effector of Ace, a collagen adhesion protein linked to virulence. J Bacteriol 2013, 195:4761-4768.
38. Carvalho AL, Turner DL, Fonseca LL, Solopova A, Catarino T, Kuipers OP, Voit EO, Neves AR, Santos H: Metabolic and transcriptional analysis of acid stress in Lactococcus lactis, with a focus on the kinetics of lactic acid pools. PLoS One 2013, 8:e68470.

39. de Jong A, Hansen ME, Kuipers OP, Kilstrup M, Kok J: The transcriptional and gene regulatory network of Lactococcus lactis MG1363 during growth in milk. PLOS ONE 2013, 8:e53085.

40. Groot Kormelink T, Koenders E, Hagemeijer Y, Overmars L, Siezen RJ, de Vos WM, Francke C: Comparative genome analysis of central nitrogen metabolism and its control by GInR in the class Bacilli. BMC Genomics 2012, 13:191.

41. Larsen R, Kloosterman TG, Kok J, Kuipers OP: GlnR-mediated regulation of nitrogen metabolism in Lactococcus lactis. J Bacteriol 2006, 188:4978-4982.

42. den Hengst CD, van Hijum SAFT, Geurts JMW, Nauta A, Kok J, Kuipers OP. The Lactococcus lactis CodY regulon: identification of a conserved cisregulatory element. J Biol Chem 2005, 280:34332-34342.

43. Guedon E, Sperandio B, Pons N, Ehrlich SD, Renault P: Overall control of nitrogen metabolism in Lactococcus lactis by CodY, and possible models for CodY regulation in Firmicutes. Microbiology 2005, 151:3895-3909.

44. Marugg JD, van Kranenburg R, Laverman P, Rutten GA, de Vos WM: Identical transcriptional control of the divergently transcribed prtP and prtM genes that are required for proteinase production in Lactococcus lactis SK11. J Bacteriol 1996, 178:1525-1531.

45. Dressaire C, Redon E, Gitton C, Loubiere P, Monnet V, Cocaign-Bousquet M: Investigation of the adaptation of Lactococcus lactis to isoleucine starvation integrating dynamic transcriptome and proteome information. Microb Cell Fact 2011, 10(Suppl 1):S18.

46. Liu F, Du L, Du P, Huo G: Possible promoter regions within the proteolytic system in Streptococcus thermophilus and their interaction with the CodY homolog. FEMS Microbiol Lett 2009, 297:164-172.

47. Hendriksen WT, Bootsma HJ, Estevao S, Hoogenboezem T, de Jong A, de Groot R, Kuipers OP, Hermans PWM: CodY of Streptococcus pneumoniae: link between nutritional gene regulation and colonization. $J$ Bacteriol 2008, 190:590-601

48. McDowell EJ, Callegari EA, Malke H, Chaussee MS: CodY-mediated regulation of Streptococcus pyogenes exoproteins. BMC Microbiol 2012, 12:114.

49. Branco dos Santos F, de Vos WM, Teusink B: Towards metagenome-scale models for industrial applications - the case of Lactic Acid Bacteria. Curr Opin Biotechnol 2013, 24:200-206.

50. Bachmann H, de Wilt L, Kleerebezem M, van Hylckama Vlieg JE: Timeresolved genetic responses of Lactococcus lactis to a dairy environment. Environ Microbiol 2010, 12:1260-1270.

51. Cretenet $M$, Laroute $V$, Ulve $V$, Jeanson $S$, Nouaille $S$, Even $S$, Piot M, Girbal L, Le Loir Y, Loubiere P, et al: Dynamic analysis of the Lactococcus lactis transcriptome in cheeses made from milk concentrated by ultrafiltration reveals multiple strategies of adaptation to stresses. Appl Environ Microbiol 2011, 77:247-257.

52. Le Boucher C, Courant F, Jeanson S, Chereau S, Maillard MB, Royer AL, Thierry A, Dervilly-Pinel G, Le Bizec B, Lortal S: First mass spectrometry metabolic fingerprinting of bacterial metabolism in a model cheese. Food Chem 2013, 141:1032-1040.

53. Taibi A, Dabour N, Lamoureux M, Roy D, LaPointe G: Comparative transcriptome analysis of Lactococcus lactis subsp. cremoris strains under conditions simulating Cheddar cheese manufacture. Int I Food Microbiol 2011, 146:263-275

54. Erkus O, de Jager VCL, Spus M, van Alen-Boerrigter IJ, van Rijswijck IMH, Hazelwood L, Janssen PWM, van Hijum SAFT, Kleerebezem M, Smid EJ: Multifactorial diversity sustains microbial community stability. ISME J 2013, 7:2126-2136.

55. Johansen P, Vindelov J, Arneborg N, Brockmann E: Development of quantitative PCR and metagenomics-based approaches for strain quantification of a defined mixed-strain starter culture. Syst Appl Microbiol 2014, 37:186-193.

56. Aguado-Urda M, Gibello A, Blanco Mdel M, Fernández-Garayzábal JF, LópezAlonso V, López-Campos GH: Global transcriptome analysis of Lactococcus garvieae strains in response to temperature. PLoS One 2013, 8:e79692.

57. Brooijmans R, Smit B, Santos F, van Riel J, de Vos WM, Hugenholtz J: Heme and menaquinone induced electron transport in lactic acid bacteria. Microb Cell Fact 2009, 8:28. 
58. Jääskeläinen $E$, Johansson $P$, Kostiainen $O$, Nieminen $T$, Schmidt $G$, Somervuo $P$, Mohsina M, Vanninen $P$, Auvinen P, Björkroth J: Significance of heme-based respiration in meat spoilage caused by Leuconostoc gasicomitatum. Appl Environ Microbiol 2013, 79:1078-1085.

59. Pedersen MB, Gaudu P, Lechardeur D, Petit MA, Gruss A: Aerobic respiration metabolism in lactic acid bacteria and uses in biotechnology. Annu Rev Food Sci Technol 2012, 3:37-58.

60. Zhai Z, Douillard FP, An H, Wang G, Guo X, Luo Y, Hao Y: Proteomic characterization of the acid tolerance response in Lactobacillus delbrueckii subsp. bulgaricus CAUH1 and functional identification of a novel acid stress-related transcriptional regulator Ldb0677. Environ Microbiol 2013, 16:1524-1537.

61. Wunsche A, Hammer E, Bartholomae M, Volker U, Burkovski A, Seidel G, Hillen W: CcpA forms complexes with CodY and RpoA in Bacillus subtilis. FEBS J 2012, 279:2201-2214.

62. Levdikov VM, Blagova $E$, Joseph $P$, Sonenshein AL, Wilkinson AJ: The structure of CodY, a GTP- and isoleucine-responsive regulator of stationary phase and virulence in gram-positive bacteria. $J \mathrm{Biol}$ Chem 2006, 281:11366-11373

63. Geiger T, Wolz C: Intersection of the stringent response and the CodY regulon in low GC Gram-positive bacteria. Int J Med Microbiol 2014, 304:150-155.

64. Wolz C, Geiger T, Goerke C: The synthesis and function of the alarmone (p)ppGpp in firmicutes. Int J Med Microbiol 2010, 300:142-147.

65. Winstedt L, Frankenberg L, Hederstedt L, von Wachenfeldt C: Enterococcus faecalis V583 contains a cytochrome bd-type respiratory oxidase. J Bacteriol 2000, 182:3863-3866.

66. Portela CAF, Smart KF, Tumanov S, Cook GM, Villas-Boas SG: The global metabolic response of Enterococcus faecalis to oxygen. J Bacteriol 2014.

67. Brooijmans RJW, Poolman B, Schuurman-Wolters GK, de Vos WM, Hugenholtz J: Generation of a membrane potential by Lactococcus lactis through aerobic electron transport. J Bacteriol 2007, 189:5203-5209.

68. Oxaran V, Ledue-Clier F, Dieye Y, Herry JM, Pechoux C, Meylheuc T, Briandet $R$, Juillard V, Piard JC: Pilus biogenesis in Lactococcus lactis: molecular characterization and role in aggregation and biofilm formation. PLoS One 2012, 7:e50989.

69. Kankainen M, Paulin L, Tynkkynen S, von Ossowski I, Reunanen J, Partanen P, Satokari R, Vesterlund S, Hendrickx APA, Lebeer S, et al: Comparative genomic analysis of Lactobacillus rhamnosus GG reveals pili containing a human- mucus binding protein. Proc Natl Acad Sci USA 2009, 106:17193-17198.

70. Segers ME, Lebeer S: Lactobacillus rhamnosus GG - host interactions. Microb Cell Fact 2014.

71. Meyrand M, Guillot A, Goin M, Furlan S, Armalyte J, Kulakauskas S, CortesPerez NG, Thomas G, Chat S, Pechoux C, et al: Surface proteome analysis of a natural isolate of Lactococcus lactis reveals the presence of pili able to bind human intestinal epithelial cells. Mol Cell Proteomics 2013, 12:3935-3947.

72. Vaughan EE, de Vries MC, Zoetendal EG, Ben-Amor K, Akkermans ADL, de Vos WM: The intestinal LABs. Antonie Van Leeuwenhoek 2002, 82:341-352.

73. Walter J: Ecological role of lactobacilli in the gastrointestinal tract: implications for fundamental and biomedical research. Appl Environ Microbiol 2008, 74:4985-4996.

74. Bello FD, Walter J, Hammes WP, Hertel C: Increased complexity of the species composition of lactic acid bacteria in human feces revealed by alternative incubation condition. Microb Ecol 2003, 45:455-463.

75. Heilig HGHJ, Zoetendal EG, Vaughan EE, Marteau P, Akkermans ADL, de Vos WM: Molecular diversity of Lactobacillus spp. and other lactic acid bacteria in the human intestine as determined by specific amplification of 16 S ribosomal DNA. Appl Environ Microbiol 2002, 68:114-123.

76. Ahrne S, Nobaek S, Jeppsson B, Adlerberth I, Wold AE, Molin G: The normal Lactobacillus flora of healthy human rectal and oral mucosa. J Appl Microbiol 1998, 85:88-94.

77. Molin G, Jeppsson B, Johansson ML, Ahrné S, Nobaek S, Stahl M, Bengmark S: Numerical taxonomy of Lactobacillus spp. associated with healthy and diseased mucosa of the human intestines. J Appl Bacteriol 1993, 74:314-323.

78. Klijn N, Weerkamp AH, de Vos WM: Genetic marking of Lactococcus lactis shows its survival in the human gastrointestinal tract. Appl Environ Microbiol 1995, 61:2771-2774.
79. David LA, Maurice CF, Carmody RN, Gootenberg DB, Button JE, Wolfe BE, Ling AV, Devlin AS, Varma Y, Fischbach MA, et al: Diet rapidly and reproducibly alters the human gut microbiome. Nature 2014, 505:559-563.

80. Douillard FP, Ribbera A, Kant R, Pietila TE, Jarvinen HM, Messing M, Randazzo CL, Paulin L, Laine P, Ritari J, et al: Comparative genomic and functional analysis of 100 Lactobacillus rhamnosus strains and their comparison with strain GG. PLoS Genet 2013, 9:e1003683.

81. Macklaim J, Fernandes A, Di Bella J, Hammond J-A, Reid G, Gloor G: Comparative meta-RNA-seq of the vaginal microbiota and differentia expression by Lactobacillus iners in health and dysbiosis. Microbiome 2013, 1:12.

82. de Vos WM, de Vos EAJ: Role of the intestinal microbiome in health and disease: from correlation to causation. Nutr Rev 2012, 70(Suppl 1):S45-56.

83. Karlsson FH, Tremaroli V, Nookaew I, Bergstrom G, Behre CJ, Fagerberg B, Nielsen J, Backhed F: Gut metagenome in European women with normal, impaired and diabetic glucose control. Nature 2013, 498:99-103.

84. de Vos WM, Nieuwdorp M: Genomics: a gut prediction. Nature 2013, 498:48-49.

85. Benítez-Páez A, Belda-Ferre P, Simón-Soro A, Mira A: Microbiota diversity and gene expression dynamics in human oral biofilms. BMC Genomics 2014, 15:311.

86. Hojo K, Mizoguchi C, Taketomo N, Ohshima T, Gomi K, Arai T, Maeda N: Distribution of salivary Lactobacillus and Bifidobacterium species in periodontal health and disease. Biosci Biotechnol Biochem 2007, 71:152-157.

87. Strahinic I, Busarcevic M, Pavlica D, Milasin J, Golic N, Topisirovic L: Molecular and biochemical characterizations of human oral lactobacilli as putative probiotic candidates. Oral Microbiol Immunol 2007, 22:111-117.

88. Jagtap P, McGowan T, Bandhakavi S, Tu ZJ, Seymour S, Griffin TJ, Rudney JD: Deep metaproteomic analysis of human salivary supernatant. Proteomics 2012, 12:992-1001.

89. Ahola AJ, Yli-Knuuttila H, Suomalainen T, Poussa T, Ahlstrom A, Meurman $\mathrm{JH}$, Korpela R: Short-term consumption of probiotic-containing cheese and its effect on dental caries risk factors. Arch Oral Biol 2002, 47:799-804.

90. Nadkarni MA, Chen Z, Wilkins MR, Hunter N: Comparative genome analysis of Lactobacillus rhamnosus clinical isolates from initial stages of dental pulp infection: identification of a new exopolysaccharide cluster. PLOS ONE 2014, 9:e90643.

91. Qin J, Li R, Raes J, Arumugam M, Burgdorf KS, Manichanh C, Nielsen T, Pons N, Levenez F, Yamada T, et al: A human gut microbial gene catalogue established by metagenomic sequencing. Nature 2010, 464:59-65.

92. Louis P, Scott KP, Duncan SH, Flint HJ: Understanding the effects of diet on bacterial metabolism in the large intestine. J Appl Microbiol 2007, 102:1197-1208.

93. Harmsen HJM, Raangs GC, He T, Degener JE, Welling GW: Extensive set of $16 \mathrm{~S}$ rRNA-based probes for detection of bacteria in human feces. Appl Environ Microbiol 2002, 68:2982-2990.

94. Booijink CCGM, El-Aidy S, Rajilić-Stojanović M, Heilig HGHJ, Troost FJ, Smidt H, Kleerebezem M, De Vos WM, Zoetendal EG: High temporal and inter-individual variation detected in the human ileal microbiota. Environ Microbiol 2010, 12:3213-3227.

95. Zoetendal EG, Raes J, van den Bogert B, Arumugam M, Booijink CCGM, Troost FJ, Bork P, Wels M, de Vos WM, Kleerebezem M: The human small intestinal microbiota is driven by rapid uptake and conversion of simple carbohydrates. ISME J 2012, 6:1415-1426.

96. van den Bogert B, Erkus O, Boekhorst J, de Goffau M, Smid EJ, Zoetendal EG, Kleerebezem M: Diversity of human small intestinal Streptococcus and Veillonella populations. FEMS Microbiol Ecol 2013, 85:376-388.

97. Bernardeau M, Guguen M, Vernoux JP: Beneficial lactobacilli in food and feed: long-term use, biodiversity and proposals for specific and realistic safety assessments. FEMS Microbiol Rev 2006, 30:487-513.

98. Vesa T, Pochart P, Marteau P: Pharmacokinetics of Lactobacillus plantarum NCIMB 8826, Lactobacillus fermentum KLD, and Lactococcus lactis MG 1363 in the human gastrointestinal tract. Aliment Pharmacol Ther 2000 14:823-828.

99. Lahti L, Salonen A, Kekkonen RA, Salojarvi J, Jalanka-Tuovinen J, Palva A, Oresic M, de Vos WM: Associations between the human intestinal 
microbiota, Lactobacillus rhamnosus GG and serum lipids indicated by integrated analysis of high-throughput profiling data. PeerJ 2013, 26.

100. Selle K, Klaenhammer TR: Genomic and phenotypic evidence for probiotic influences of Lactobacillus gasseri on human health. FEMS Microbiol Rev 2013, 37:915-935.

101. Denou E, Pridmore RD, Berger B, Panoff JM, Arigoni F, Brussow H: Identification of genes associated with the long-gut-persistence phenotype of the probiotic Lactobacillus johnsonii strain NCC533 using a combination of genomics and transcriptome analysis. J Bacteriol 2008, 190:3161-3168.

102. Toh H, Oshima K, Nakano A, Takahata M, Murakami M, Takaki T, Nishiyama H, Igimi S, Hattori M, Morita H: Genomic Adaptation of the Lactobacillus casei Group. PLOS ONE 2013, 8:e75073.

103. Cai H, Rodríguez BT, Zhang W, Broadbent JR, Steele JL: Genotypic and phenotypic characterization of Lactobacillus casei strains isolated from different ecological niches suggests frequent recombination and niche specificity. Microbiol 2007, 153:2655-2665.

104. Raftis EJ, Salvetti E, Torriani S, Felis GE, OToole PW: Genomic diversity of Lactobacillus salivarius. Appl Environ Microbiol 2011, 77:954-965.

105. Corr SC, Li Y, Riedel CU, OToole PW, Hill C, Gahan CG: Bacteriocin production as a mechanism for the antiinfective activity of Lactobacillus salivarius UCC118. Proc Natl Acad Sci USA 2007, 104:7617-7621.

106. Claesson MJ, Li Y, Leahy S, Canchaya C, van Pijkeren JP, CerdeñoTárraga AM, Parkhill J, Flynn S, O'Sullivan GC, Collins JK, et al: Multireplicon genome architecture of Lactobacillus salivarius. Proc Natl Acad Sci USA 2006, 103:6718-6723.

107. Naito S, Hayashidani H, Kaneko K, Ogawa M, Benno Y: Development of intestinal lactobacilli in normal piglets. J Appl Bacteriol 1995, 79:230-236.

108. Molin G, Johansson ML, Ståhl M, Ahrné S, Andersson R, Jeppsson B, Bengmark S: Systematics of the Lactobacillus population on rat intestinal mucosa with special reference to Lactobacillus reuteri. Antonie Van Leeuwenhoek 1992, 61:175-183.

109. Frese SA, Benson AK, Tannock GW, Loach DM, Kim J, Zhang M, Oh PL, Heng NCK, Patil PB, Juge N, et al: The Evolution of host specialization in the vertebrate gut symbiont Lactobacillus reuteri. PLOS Genet 2011, 7: e1001314.

110. Moran NA, Plague GR: Genomic changes following host restriction in bacteria. Curr Opin Genet Dev 2004, 14:627-633.

111. Forde BM, Neville BA, O'Donnell MM, Riboulet-Bisson E, Claesson MJ, Coghlan A, Ross RP, OToole PW: Genome sequences and comparative genomics of two Lactobacillus ruminis strains from the bovine and human intestinal tracts. Microb Cell Fact 2011, 10(Suppl 1):S13.

112. Altermann E, Russell WM, Azcarate-Peril MA, Barrangou R, Buck BL, McAuliffe O, Souther N, Dobson A, Duong T, Callanan M, et al: Complete genome sequence of the probiotic lactic acid bacterium Lactobacillus acidophilus NCFM. Proc Natl Acad Sci USA 2005, 102:3906-3912.

113. Callanan M, Kaleta P, O'Callaghan J, O'Sullivan O, Jordan K, MCAuliffe O, Sangrador-Vegas A, Slattery L, Fitzgerald GF, Beresford T, Ross RP: Genome sequence of Lactobacillus helveticus, an organism distinguished by selective gene loss and insertion sequence element expansion. J Bacteriol 2008, 190:727-735.

114. Douillard FP, Ribbera A, Järvinen HM, Kant R, Pietilä TE, Randazzo C, Paulin L, Laine PK, Caggia C, von Ossowski l, et al: Comparative genomic and functional analysis of Lactobacillus casei and Lactobacillus rhamnosus strains marketed as probiotics. Appl Environ Microbiol 2013, 79:1923-1933.

115. van Pijkeren JP, Canchaya C, Ryan KA, Li Y, Claesson MJ, Sheil B, Steidler L, O'Mahony L, Fitzgerald GF, van Sinderen D, O'Toole PW: Comparative and functional analysis of sortase-dependent proteins in the predicted secretome of Lactobacillus salivarius UCC118. Appl Environ Microbiol 2006, 72:4143-4153.

116. Call EK, Klaenhammer TR: Relevance and application of sortase and sortase-dependent proteins in lactic acid bacteria. Front Microbiol 2013, 4:73.

117. Neville BA, Forde BM, Claesson MJ, Darby T, Coghlan A, Nally K, Ross RP, OToole PW: Characterization of pro-inflammatory flagellin proteins produced by Lactobacillus ruminis and related motile lactobacilli. PLOS ONE 2012, 7:e40592.

118. Azcarate-Peril MA, Altermann E, Goh YJ, Tallon R, Sanozky-Dawes RB, Pfeiler EA, O'Flaherty S, Buck BL, Dobson A, Duong T, et al: Analysis of the genome sequence of Lactobacillus gasseri ATCC 33323 reveals the molecular basis of an autochthonous intestinal organism. Appl Environ Microbiol 2008, 74:4610-4625.

119. Yanagihara S, Hirota T, Yamamoto N: Transcriptional response of Lactobacillus acidophilus L-92 after attachment to epithelial Caco-2 cells. J Biosci Bioeng 2012, 114:582-585.

120. Ashida N, Yanagihara S, Shinoda T, Yamamoto N: Characterization of adhesive molecule with affinity to Caco-2 cells in Lactobacillus acidophilus by proteome analysis. J Biosci Bioeng 2011, 112:333-337.

121. Konstantinov SR, Smidt H, de Vos WM, Bruijns SCM, Singh SK, Valence F, Molle D, Lortal S, Altermann E, Klaenhammer TR, van Kooyk Y: S layer protein A of Lactobacillus acidophilus NCFM regulates immature dendritic cell and T cell functions. Proc Natl Acad Sci USA 2008, 105:19474-19479.

122. Johnson B, Selle K, O'Flaherty S, Goh YJ, Klaenhammer T: Identification of extracellular surface-layer associated proteins in Lactobacillus acidophilus NCFM. Microbiology 2013, 159:2269-2282.

123. Koskenniemi K, Laakso K, Koponen J, Kankainen M, Greco D, Auvinen P, Savijoki K, Nyman TA, Surakka A, Salusjärvi T, et al: Proteomics and transcriptomics characterization of bile stress response in probiotic Lactobacillus rhamnosus GG. Mol Cell Prot 2011, 10.

124. Koponen J, Laakso K, Koskenniemi K, Kankainen M, Savijoki K, Nyman TA, de Vos WM, Tynkkynen S, Kalkkinen N, Varmanen P: Effect of acid stress on protein expression and phosphorylation in Lactobacillus rhamnosus GG. J Proteomics 2012, 75:1357-1374.

125. Alcántara C, Zúñiga M: Proteomic and transcriptomic analysis of the response to bile stress of Lactobacillus casei BL23. Microbiology 2012, 158:1206-1218.

126. Goh YJ, Klaenhammer TR: A functional glycogen biosynthesis pathway in Lactobacillus acidophilus: expression and analysis of the glg operon. Mol Microbiol 2013, 89:1187-1200.

127. Bron PA, Grangette C, Mercenier A, de Vos WM, Kleerebezem M: Identification of Lactobacillus plantarum genes that are induced in the gastrointestinal tract of mice. J Bacteriol 2004, 186:5721-5729.

128. Troost FJ, van Baarlen P, Lindsey P, Kodde A, de Vos WM, Kleerebezem M, Brummer RJ: Identification of the transcriptional response of human intestinal mucosa to Lactobacillus plantarum WCFS1 in vivo. BMC Genomics 2008, 9:374.

129. van Baarlen P, Troost FJ, van Hemert S, van der Meer C, de Vos WM, de Groot PJ, Hooiveld GJEJ, Brummer RJ, Kleerebezem M: Differential NFkappaB pathways induction by Lactobacillus plantarum in the duodenum of healthy humans correlating with immune tolerance. Proc Natl Acad Sci USA 2009, 106:2371-2376.

130. Marco ML, Peters THF, Bongers RS, Molenaar D, Van Hemert S, Sonnenburg JL, Gordon Jl, Kleerebezem M: Lifestyle of Lactobacillus plantarum in the mouse caecum. Environ Microbiol 2009, 11:2747-2757.

131. Marco ML, de Vries MC, Wels M, Molenaar D, Mangell P, Ahrne S, de Vos WM, Vaughan EE, Kleerebezem M: Convergence in probiotic Lactobacillus gut-adaptive responses in humans and mice. ISME J 2010, 4:1481-1484.

132. Reverón I, de las Rivas B, Muñoz R, López de Felipe F: Genome-wide transcriptomic responses of a human isolate of Lactobacillus plantarum exposed to p-coumaric acid stress. Molecular Nutrition \& Food Research 2012, 56:1848-1859.

133. Bron PA, Marco M, Hoffer SM, Van Mullekom E, de Vos WM, Kleerebezem M: Genetic characterization of the bile salt response in Lactobacillus plantarum and analysis of responsive promoters in vitro and in situ in the gastrointestinal tract. J Bacteriol 2004, 186:7829-7835.

134. Hamon E, Horvatovich P, Izquierdo E, Bringel F, Marchioni E, AoudeWerner D, Ennahar S: Comparative proteomic analysis of Lactobacillus plantarum for the identification of key proteins in bile tolerance. BMC Microbiol 2011, 11:63.

135. van Bokhorst-van de Veen $H$, Smelt MJ, Wels M, van Hijum SAFT, de Vos $P$, Kleerebezem M, Bron PA: Genotypic adaptations associated with prolonged persistence of Lactobacillus plantarum in the murine digestive tract. Biotechnol J 2013, 8:895-904.

136. Kim JF, Jeong H, Lee JS, Choi SH, Ha M, Hur CG, Kim JS, Lee S, Park HS, Park YH, Oh TK: Complete genome sequence of Leuconostoc citreum KM20. J Bacteriol 2008, 190:3093-3094.

137. Lee K, Pi K: Effect of transient acid stress on the proteome of intestinal probiotic Lactobacillus reuteri. Biochemistry (Mosc) 2010, 75:460-465. 
138. Denou E, Berger B, Barretto C, Panoff JM, Arigoni F, Brussow H: Gene expression of commensal Lactobacillus johnsonii strain NCC533 during in vitro growth and in the murine gut. J Bacteriol 2007, 189:8109-8119.

139. Pendharkar S, Magopane T, Larsson PG, de Bruyn G, Gray GE, Hammarstrom L, Marcotte H: Identification and characterisation of vaginal lactobacilli from South African women. BMC Infect Dis 2013, 13:43.

140. Martínez-Peña MD, Castro-Escarpulli G, Aguilera-Arreola MG: Lactobacillus species isolated from vaginal secretions of healthy and bacterial vaginosis-intermediate Mexican women: a prospective study. BMC Infect Dis 2013, 13:189.

141. Zhou X, Hansmann MA, Davis CC, Suzuki H, Brown CJ, Schutte U, Pierson JD, Forney LJ: The vaginal bacterial communities of Japanese women resemble those of women in other racial groups. FEMS Immunol Med Microbiol 2010, 58:169-181.

142. Ravel J, Gajer P, Abdo Z, Schneider GM, Koenig SSK, McCulle SL, Karlebach S, Gorle R, Russell J, Tacket CO, et al: Vaginal microbiome of reproductive-age women. Proc Natl Acad Sci USA 2011, 108(Suppl 1):4680-4687.

143. Zhou X, Brown CJ, Abdo Z, Davis CC, Hansmann MA, Joyce P, Foster JA Forney $L$ : Differences in the composition of vaginal microbial communities found in healthy Caucasian and black women. ISME J 2007, 1:121-133

144. Drell T, Lillsaar T, Tummeleht L, Simm J, Aaspõllu A, Vain E, Saarma I, Salumets A, Donders GGG, Metsis M: Characterization of the vaginal micro- and mycobiome in asymptomatic reproductive-age Estonian women. PloS One 2013, 8:e54379.

145. Motevaseli E, Shirzad M, Raoofian R, Hasheminasab SM, Hatami M, Dianatpour M, Modarressi MH: Differences in vaginal lactobacilli composition of Iranian healthy and bacterial vaginosis infected women: a comparative analysis of their cytotoxic effects with commercial vaginal probiotics. Iran Red Crescent Med J 2013, 15:199-206.

146. Antonio MA, Hawes SE, Hillier SL: The identification of vaginal Lactobacillus species and the demographic and microbiologic characteristics of women colonized by these species. J Infect Dis 1999, 180:1950-1956.

147. Shipitsyna E, Roos A, Datcu R, Hallén A, Fredlund H, Jensen JS, Engstrand L, Unemo M: Composition of the vaginal microbiota in women of reproductive age-sensitive and specific molecular diagnosis of bacterial vaginosis is possible? PLoS One 2013, 8:e60670.

148. O'Hanlon DE, Moench TR, Cone RA: Vaginal $\mathrm{pH}$ and microbicidal lactic acid when lactobacilli dominate the microbiota. PLoS One 2013, 8:e80074.

149. Vera Pingitore E, Hebert EM, Nader-Macias ME, Sesma F: Characterization of salivaricin CRL 1328, a two-peptide bacteriocin produced by Lactobacillus salivarius CRL 1328 isolated from the human vagina. Res Microbiol 2009, 160:401-408.

150. Kaewnopparat S, Dangmanee N, Kaewnopparat N, Srichana T, Chulasiri M, Settharaksa S: In vitro probiotic properties of Lactobacillus fermentum SK5 isolated from vagina of a healthy woman. Anaerobe 2013, 22:6-13.

151. Homayouni A, Bastani P, Ziyadi S, Mohammad-Alizadeh-Charandabi S, Ghalibaf M, Mortazavian AM, Mehrabany EV: Effects of probiotics on the recurrence of bacterial vaginosis: a review. J Low Genit Tract Dis 2014, 18:79-86.

152. Mastromarino P, Vitali B, Mosca L: Bacterial vaginosis: a review on clinical trials with probiotics. New Microbiol 2013, 36:229-238.

153. Mendes-Soares H, Suzuki H, Hickey RJ, Forney LJ: Comparative functional genomics of Lactobacillus spp. reveals possible mechanisms for specialization of vaginal lactobacilli to their environment. J Bacterio/ 2014, 196:1458-1470.

154. Macklaim JM, Gloor GB, Anukam KC, Cribby S, Reid G: At the crossroads of vaginal health and disease, the genome sequence of Lactobacillus iners AB-1. Proc Natl Acad Sci USA 2011, 108(Suppl 1):4688-4695.

155. Murata K, Hoshina T, Saito M, Ohkusu K, Yamamura K, Tanoue Y, Ihara K, Hara T: Bacterial pericarditis caused by Lactobacillus iners in an infant. Diagn Microbiol Infect Dis 2012, 74:181-182.

156. Tanaka Y, Watanabe J, Mogi Y: Monitoring of the microbial communities involved in the soy sauce manufacturing process by PCR-denaturing gradient gel electrophoresis. Food Microbiol 2012, 31:100-106.

157. McMillan A, Macklaim JM, Burton JP, Reid G: Adhesion of Lactobacillus iners $A B-1$ to human fibronectin: a key mediator for persistence in the vagina? Reprod Sci 2013, 20:791-796.

158. Osset J, Bartolomé RM, García E, Andreu A: Assessment of the capacity of Lactobacillus to inhibit the growth of uropathogens and block their adhesion to vaginal epithelial cells. J Infect Dis 2001, 183:485-491.
159. Saunders S, Bocking A, Challis J, Reid G: Effect of Lactobacillus challenge on Gardnerella vaginalis biofilms. Colloids Surf B Biointerfaces 2007, 55:138-142.

160. Rampersaud R, Planet PJ, Randis TM, Kulkarni R, Aguilar JL, Lehrer Rl, Ratner AJ: Inerolysin, a cholesterol-dependent cytolysin produced by Lactobacillus iners. J Bacteriol 2011, 193:1034-1041.

161. Malik S, Petrova MI, Claes IJJ, Verhoeven TLA, Busschaert P, Vaneechoutte M, Lievens B, Lambrichts I, Siezen RJ, Balzarini J, et al: The highly autoaggregative and adhesive phenotype of the vaginal Lactobacillus plantarum strain CMPG5300 is sortase dependent. Appl Environ Microbiol 2013, 79:4576-4585.

162. Bohbot JM, Cardot JM: Vaginal impact of the oral administration of total freeze-dried culture of LCR 35 in healthy women. Infect Dis Obstet Gynecol 2012, 2012:503648.

163. Parma M, Dindelli M, Caputo L, Redaelli A, Quaranta L, Candiani M: The role of vaginal Lactobacillus Rhamnosus (Normogin(R)) in preventing Bacterial Vaginosis in women with history of recurrences, undergoing surgical menopause: a prospective pilot study. Eur Rev Med Pharmacol Sci 2013, 17:1399-1403.

164. Colodner R, Edelstein H, Chazan B, Raz R: Vaginal colonization by orally administered Lactobacillus rhamnosus GG. Isr Med Assoc J 2003, 5:767-769.

165. EFSA BIOHAZ Panel (EFSA Panel on Biological Hazards): Scientific Opinion on the maintenance of the list of QPS biological agents intentionally added to food and feed (2013 update). EFSA Journal 2013, 11:108.

166. Foulquié Moreno MR, Sarantinopoulos P, Tsakalidou E, De Vuyst L: The role and application of enterococci in food and health. Int J Food Microbiol 2006, 106:1-24.

167. Lebreton F, Willems RJL, Gilmore MS: Enterococcus Diversity, Origins in Nature, and Gut Colonization. In Enterococci: From commensals to leading causes of drug resistant infection. Boston;Gilmore MS, Clewell DB, Ike $Y$, Shankar N 2014.

168. Gilmore MS, Lebreton F, van Schaik W: Genomic transition of enterococc from gut commensals to leading causes of multidrug-resistant hospital infection in the antibiotic era. Curr Opin Microbiol 2013, 16:10-16.

169. Galloway-Peña J, Roh JH, Latorre M, Qin X, Murray BE: Genomic and SNP analyses demonstrate a distant separation of the hospital and communityassociated clades of Enterococcus faecium. PLoS One 2012, 7:e30187.

170. Lukjancenko O, Ussery DW, Wassenaar TM: Comparative genomics of Bifidobacterium, Lactobacillus and related probiotic genera. Microb Ecol 2012, 63:651-673.

171. Gouriet F, Million M, Henri M, Fournier PE, Raoult D: Lactobacillus rhamnosus bacteremia: an emerging clinical entity. Eur J Clin Microbiol Infect Dis 2012, 31:2469-2480.

172. Salminen MK, Tynkkynen S, Rautelin H, Saxelin M, Vaara M, Ruutu P, Sarna S, Valtonen $V$, Järvinen $A$ : Lactobacillus bacteremia during a rapid increase in probiotic use of Lactobacillus rhamnosus GG in Finland. Clin Infect Dis 2002, 35:1155-1160.

173. Plumed-Ferrer C, Uusikyla K, Korhonen J, von Wright A: Characterization of Lactococcus lactis isolates from bovine mastitis. Vet Microbiol 2013, 167:592-599.

174. Hadjisymeou S, Loizou P, Kothari P: Lactococcus lactis cremoris infection: not rare anymore? BMJ Case Rep 2013, 2013.

175. Inoue M, Saito A, Kon H, Uchida H, Koyama S, Haryu S, Sasaki T, Nishijima M: Subdural empyema due to Lactococcus lactis cremoris: case report. Neurol Med Chir (Tokyo) 2014, 54:341-317.

176. Santer M: Joseph Lister: first use of a bacterium as a 'model organism' to illustrate the cause of infectious disease of humans. Notes Rec $R$ Soc Lond 2010, 64:59-65.

177. Zwielehner J, Handschur M, Michaelsen A, Irez S, Demel M, Denner EBM, Haslberger AG: DGGE and real-time PCR analysis of lactic acid bacteria in bacterial communities of the phyllosphere of lettuce. Mol Nutr Food Res 2008, 52:614-623.

178. Braem G, De Vliegher S, Verbist B, Piessens V, Van Coillie E, De Vuyst L, Leroy F: Unraveling the microbiota of teat apices of clinically healthy lactating dairy cows, with special emphasis on coagulase-negative staphylococci. J Dairy Sci 2013, 96:1499-1510.

179. Bayjanov JR, Starrenburg MJC, van der Sijde MR, Siezen RJ, van Hijum SAFT: Genotype-phenotype matching analysis of 38 Lactococcus lactis strains using random forest methods. BMC Microbiol 2013, 13:68.

180. McCutcheon JP, Moran NA: Extreme genome reduction in symbiotic bacteria. Nat Rev Micro 2012, 10:13-26. 
181. Bolotin A, Quinquis B, Renault P, Sorokin A, Ehrlich SD, Kulakauskas S, Lapidus A, Goltsman E, Mazur M, Pusch GD, et al: Complete sequence and comparative genome analysis of the dairy bacterium Streptococcus thermophilus. Nat Biotechnol 2004, 22:1554-1558.

182. Pittet $V$, Abegunde T, Marfleet T, Haakensen M, Morrow K, Jayaprakash T, Schroeder K, Trost B, Byrns S, Bergsveinson J, et al: Complete genome sequence of the beer spoilage organism Pediococcus claussenii ATCC BAA-344T. J Bacteriol 2012, 194:1271-1272.

183. Broadbent JR, Neeno-Eckwall EC, Stahl B, Tandee K, Cai H, Morovic W, Horvath P, Heidenreich J, Perna NT, Barrangou R, Steele JL: Analysis of the Lactobacillus casei supragenome and its influence in species evolution and lifestyle adaptation. BMC Genomics 2012, 13:533.

184. Nicolas P, Bessieres P, Ehrlich SD, Maguin E, van de Guchte M: Extensive horizontal transfer of core genome genes between two Lactobacillus species found in the gastrointestinal tract. BMC Evol Biol 2007, 7:141.

185. Cai H, Thompson R, Budinich MF, Broadbent JR, Steele JL: Genome sequence and comparative genome analysis of Lactobacillus casei: insights into their niche-associated evolution. Genome Biol Evol 2009, $1: 239-257$

186. Douillard FP, Kant R, Ritari J, Paulin L, Palva A, de Vos WM: Comparative genome analysis of Lactobacillus casei strains isolated from Actimel and Yakult products reveals marked similarities and points to a common origin. Microb Biotechnol 2013, 6:576-587.

187. Linares DM, Geertsma ER, Poolman B: Evolved Lactococcus lactis strains for enhanced expression of recombinant membrane proteins. J Mol Biol 2010, 401:45-55.

188. Bachmann H, Starrenburg MJ, Molenaar D, Kleerebezem M, van Hylckama Vlieg JET: Microbial domestication signatures of Lactococcus lactis can be reproduced by experimental evolution. Genome Res 2012, 22:115-124.

189. Bachmann H, Fischlechner M, Rabbers I, Barfa N, Branco dos Santos F, Molenaar D, Teusink B: Availability of public goods shapes the evolution of competing metabolic strategies. Proc Natl Acad Sci USA 2013, 110:14302-14307.

190. Kleerebezem M, Hols P, Bernard E, Rolain T, Zhou M, Siezen RJ, Bron PA: The extracellular biology of the lactobacilli. FEMS Microbiol Rev 2010, 34:199-230.

191. Brown J, de Vos WM, DiStefano PS, Dore J, Huttenhower C, Knight R, Lawley TD, Raes J, Turnbaugh P: Translating the human microbiome. Nat Biotechnol 2013, 31:304-308.

192. Kuipers OP, Beerthuyzen MM, de Ruyter PG, Luesink EJ, de Vos WM: Autoregulation of nisin biosynthesis in Lactococcus lactis by signal transduction. J Biol Chem 1995, 270:27299-27304.

193. Barrangou R, Fremaux C, Deveau H, Richards M, Boyaval P, Moineau S, Romero DA, Horvath P: CRISPR provides acquired resistance against viruses in prokaryotes. Science 2007, 315:1709-1712

194. Desguin B, Goffin P, Viaene E, Kleerebezem M, Martin-Diaconescu V, Maroney MJ, Declercq J-P, Soumillion P, Hols P: Lactate racemase is a nickel-dependent enzyme activated by a widespread maturation system. Nat Commun 2014, 5.

195. Kant R, Paulin L, Alatalo E, de Vos WM, Palva A: Genome sequence of Lactobacillus amylovorus GRL1112. J Bacterio/ 2011, 193:789-790.

196. Mazé A, Boël G, Zúñiga M, Bourand A, Loux V, Yebra MJ, Monedero V, Correia $K$, Jacques N, Beaufils $S$, et al: Complete genome sequence of the probiotic Lactobacillus casei strain BL23. J Bacteriol 2010, 192:2647-2648.

197. Morita H, Toh H, Fukuda S, Horikawa H, Oshima K, Suzuki T, Murakami M, Hisamatsu S, Kato Y, Takizawa T, et al: Comparative genome analysis of Lactobacillus reuteri and Lactobacillus fermentum reveal a genomic island for reuterin and cobalamin production. DNA Res 2008, 15:151-161.

198. Pridmore RD, Berger B, Desiere F, Vilanova D, Barretto C, Pittet AC, Zwahlen MC, Rouvet M, Altermann E, Barrangou R, et al: The genome sequence of the probiotic intestinal bacterium Lactobacillus johnsonii NCC 533. Proc Natl Acad Sci USA 2004, 101:2512-2517.

199. Wang Y, Wang J, Ahmed Z, Bai X, Wang J: Complete genome sequence of Lactobacillus kefiranofaciens ZW3. J Bacteriol 2011, 193:4280-4281.

200. Wang S, Zhu H, He F, Luo Y, Kang Z, Lu C, Feng L, Lu X, Xue Y, Wang H: Whole genome sequence of the probiotic strain Lactobacillus paracasei $\mathrm{N} 1115$, isolated from traditional chinese fermented milk. Genome Announc 2014, 2.

201. Siezen RJ, Francke C, Renckens B, Boekhorst J, Wels M, Kleerebezem M, van Hijum SAFT: Complete resequencing and reannotation of the Lactobacillus plantarum WCFS1 genome. J Bacteriol 2012, 194:195-196.
202. Chaillou S, Champomier-Vergès MC, Cornet M, Crutz-Le Coq AM, Dudez AM, Martin V, Beaufils S, Darbon-Rongere E, Bossy R, Loux V, Zagorec M: The complete genome sequence of the meat-borne lactic acid bacterium Lactobacillus sakei 23K. Nat Biotechnol 2005, 23:1527-1533.

203. Wegmann U, O'Connell-Motherway M, Zomer A, Buist G, Shearman C, Canchaya C, Ventura M, Goesmann A, Gasson MJ, Kuipers OP, et al: Complete genome sequence of the prototype lactic acid bacterium Lactococcus lactis subsp. cremoris MG1363. J Bacteriol 2007, 189:3256-3270.

204. Paulsen IT, Banerjei L, Myers GS, Nelson KE, Seshadri R, Read TD, Fouts DE, Eisen JA, Gill SR, Heidelberg JF, et al: Role of mobile DNA in the evolution of vancomycin-resistant Enterococcus faecalis. Science 2003, 299:2071-2074.

205. Qin X, Galloway-Peña JR, Sillanpaa J, Roh JH, Nallapareddy SR, Chowdhury S, Bourgogne A, Choudhury T, Muzny DM, Buhay CJ, et al: Complete genome sequence of Enterococcus faecium strain TX16 and comparative genomic analysis of Enterococcus faecium genomes. BMC Microbiol 2012, 12:135.

206. Jung JY, Lee SH, Jeon CO: Complete genome sequence of Leuconostoc gelidum strain JB7, isolated from kimchi. J Bacteriol 2012, 194:6665.

207. Jung JY, Lee SH, Jeon CO: Complete genome sequence of Leuconostoc carnosum strain JB16, isolated from kimchi. J Bacteriol 2012, 194:6672-6673.

208. Oh HM, Cho YJ, Kim BK, Roe JH, Kang SO, Nahm BH, Jeong G, Han HU, Chun J: Complete genome sequence analysis of Leuconostoc kimchii IMSNU 11154. J Bacteriol 2010, 192:3844-3845

209. Johansson P, Paulin L, Säde E, Salovuori N, Alatalo ER, Björkroth KJ, Auvinen P: Genome sequence of a food spoilage lactic acid bacterium, Leuconostoc gasicomitatum LMG 18811T, in association with specific spoilage reactions. Appl Environ Microbiol 2011, 77:4344-4351.

210. Dereeper A, Audic S, Claverie JM, Blanc G: BLAST-EXPLORER helps you building datasets for phylogenetic analysis. BMC Evol Biol 2010, 10:8

211. Dereeper A, Guignon V, Blanc G, Audic S, Buffet S, Chevenet F, Dufayard JF, Guindon S, Lefort $V$, Lescot $M$, et al: Phylogeny.fr: robust phylogenetic analysis for the non-specialist. Nucleic Acids Res 2008, 36:W465-469.

212. Edgar RC: MUSCLE: multiple sequence alignment with high accuracy and high throughput. Nucleic Acids Res 2004, 32:1792-1797.

213. Castresana J: Selection of conserved blocks from multiple alignments for their use in phylogenetic analysis. Mol Biol Evol 2000, 17:540-552.

214. Guindon S, Gascuel O: A simple, fast, and accurate algorithm to estimate large phylogenies by maximum likelihood. Syst Biol 2003, 52:696-704.

215. Anisimova M, Gascuel O: Approximate likelihood-ratio test for branches: A fast, accurate, and powerful alternative. Syst Biol 2006, 55:539-552.

216. Chevenet F, Brun C, Bañuls AL, Jacq B, Christen R: TreeDyn: towards dynamic graphics and annotations for analyses of trees. $B M C$ Bioinformatics 2006, 7:439.

217. Charif D, Lobry J: SeqinR 1.0-2: a contributed package to the R project for statistical computing devoted to biological sequences retrieval and analysis. In Structural Approaches to Sequence Evolution. Springer Berlin Heidelberg;Bastolla U, Porto M, Roman HE, Vendruscolo M 2007:207-232, Biological and Medical Physics, Biomedical Engineering.

218. Pages H, Aboyoun P, Gentleman R, DebRoy S: Biostrings: String objects representing biological sequences, and matching algorithms. 2013, R package version 2.28.0. edition.

219. Stuben C: genomes: Genome sequencing project metadata. 2013, R package version 2.6.0. edition.

220. Bik EM, Eckburg PB, Gill SR, Nelson KE, Purdom EA, Francois F, PerezPerez G, Blaser MJ, Relman DA: Molecular analysis of the bacterial microbiota in the human stomach. Proc Natl Acad Sci USA 2006, 103:732-737

221. Booijink CCGM, Zoetendal EG, Kleerebezem M, de Vos WM: Microbial communities in the human small intestine: coupling diversity to metagenomics. Future Microbiol 2007, 2:285-295.

doi:10.1186/1475-2859-13-S1-S8

Cite this article as: Douillard and de Vos: Functional genomics of lactic acid bacteria: from food to health. Microbial Cell Factories 2014 13(Suppl 1):S8 